\title{
\#USGS
}

science for a changing world

Prepared in cooperation with the Providence Water Supply Board

- Streamflow, Water Quality, and Constituent Loads and Yields, Scituate Reservoir Drainage Area,

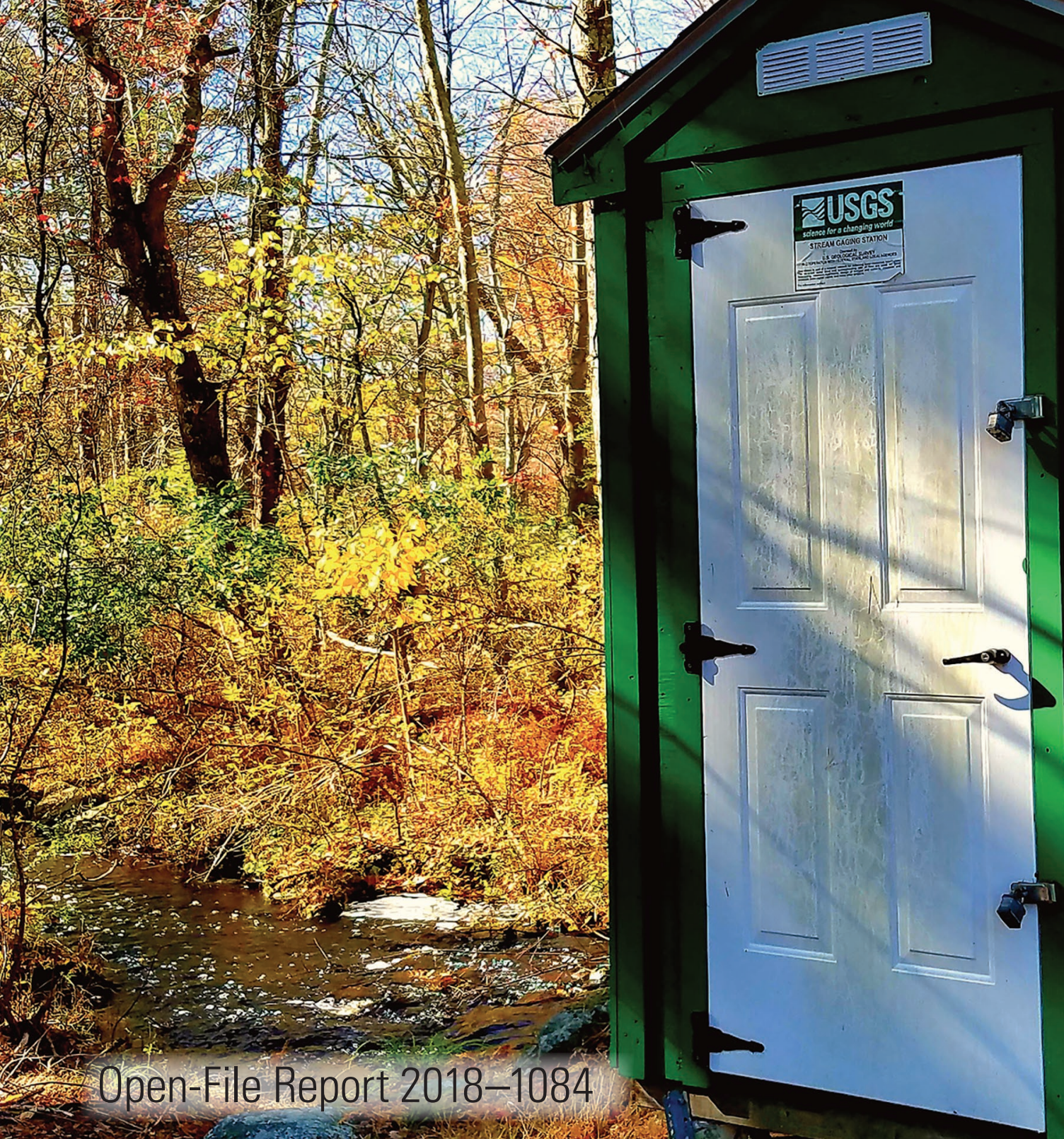

ST.

Streamflow, Water Quality, and Constituent Loads Water Year 2016 Water Year 2016 at 
Cover. U.S. Geological Survey streamgage at Quonopaug Brook at State Route 116 near North Scituate, Rhode Island; photograph by the U.S. Geological Survey. 


\section{Streamflow, Water Quality, and Constituent Loads and Yields, Scituate Reservoir Drainage Area, Rhode Island, Water Year 2016}

By Kirk P. Smith

Prepared in cooperation with the Providence Water Supply Board

Open-File Report 2018-1084 


\section{U.S. Department of the Interior \\ RYAN K. ZINKE, Secretary}

\section{U.S. Geological Survey James F. Reilly II, Director}

\section{U.S. Geological Survey, Reston, Virginia: 2018}

For more information on the USGS - the Federal source for science about the Earth, its natural and living resources, natural hazards, and the environment-visit https://www.usgs.gov or call 1-888-ASK-USGS.

For an overview of USGS information products, including maps, imagery, and publications, visit https://store.usgs.gov.

Any use of trade, firm, or product names is for descriptive purposes only and does not imply endorsement by the U.S. Government.

Although this information product, for the most part, is in the public domain, it also may contain copyrighted materials as noted in the text. Permission to reproduce copyrighted items must be secured from the copyright owner.

Suggested citation:

Smith, K.P., 2018, Streamflow, water quality, and constituent loads and yields, Scituate Reservoir drainage area, Rhode Island, water year 2016: U.S. Geological Survey Open-File Report 2018-1084, 32 p., https://doi.org/10.3133/ ofr20181084.

ISSN 2331-1258 (online) 


\section{Contents}

Abstract

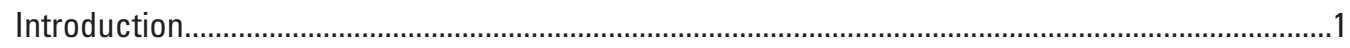

Streamflow Data Collection and Estimation...............................................................................

Water-Quality Data Collection and Analysis .......................................................................................

Data Collected by the U.S. Geological Survey .............................................................................

Data Collected by the Providence Water Supply Board ........................................................

Estimating Daily, Monthly, and Annual Loads and Yields..........................................................

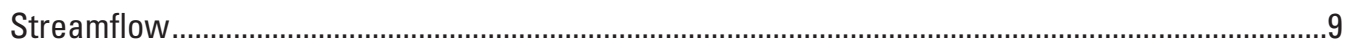

Water Quality and Constituent Loads and Yields ............................................................................

Chloride and Sodium Loads and Yields Estimated From Specific-Conductance

Monitoring Data..............................................................................................................

Physical and Chemical Properties and Daily Loads and Yields Estimated From Data

Collected by the Providence Water Supply Board ....................................................... 11

Physical and Chemical Properties .......................................................................................11

Constituent Concentrations and Daily Loads and Yields.................................................11

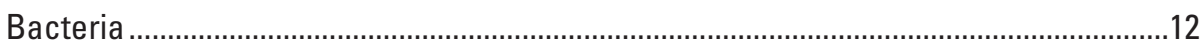

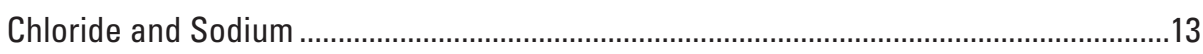

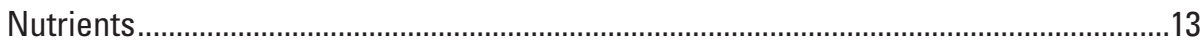

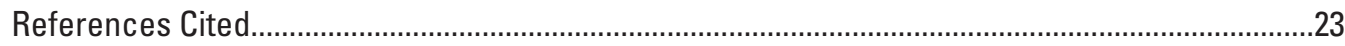

\section{Figures}

1. Map showing locations of tributary-reservoir subbasins and stations in the Scituate Reservoir drainage area, Rhode Island, in water year 2016...............................2

2. Graph showing flow-duration curve and streamflow on the dates when waterquality samples were collected for the U.S. Geological Survey continuous streamgage on Rush Brook near Elmdale Road North Scituate, Rhode Island, in water year 2016.

3. Graph showing measured daily mean streamflow for October 1, 2015, through September 30, 2016, and the 10th percentile, median, and 90th percentile values of daily streamflow for October 1, 1994, through September 30, 2015, for the U.S. Geological Survey continuous-record streamgage on the Ponaganset River at South Foster in the Scituate Reservoir drainage area, Rhode Island

4. Graph showing annual loads of chloride and sodium estimated from streamflow and specific conductance data for water year 2016 and associated minimum, maximum, and median annual loads for water years 2009-15 at 14 Providence Water Supply Board stations in the Scituate Reservoir drainage area, Rhode Island 


\section{Tables}

1. Providence Water Supply Board water-quality sampling stations, water-quality samples, and available streamflow and specific conductance monitoring in the Scituate Reservoir drainage area, Rhode Island, from October 1, 2015, to September 30, 2016

2. Measured or estimated annual mean streamflow for tributary streams in the Scituate Reservoir drainage area, Rhode Island, from October 1, 2015, through September 30, 2016.

3. Regression equation coefficients used to estimate concentrations of chloride and sodium from values of specific conductance for U.S. Geological Survey monitoring stations in the Scituate Reservoir drainage area, Rhode Island, from October 1, 2015, through September 30, 2016

4. Daily loads of bacteria, chloride, nitrite, nitrate, and orthophosphate in the Scituate Reservoir drainage area, Rhode Island, from October 1, 2015, through September 30, 2016.

5. Monthly mean concentrations of chloride and sodium estimated from continuous measurements of specific conductance in the Scituate Reservoir drainage area, Rhode Island, from October 1, 2015, through September 30, 2016

6. Annual mean chloride and sodium concentrations, loads, and yields for sampling stations in the Scituate Reservoir drainage area, Rhode Island, from October 1, 2015, through September 30, 2016

7. Monthly estimated chloride and sodium loads for sampling stations in the Scituate Reservoir drainage area, Rhode Island, from October 1, 2015, through September 30, 2016.

8. Median values for water-quality data collected at Providence Water Supply Board stations in the Scituate Reservoir drainage area, Rhode Island, from October 1, 2015, through September 30, 2016

9. Median daily loads and yields of bacteria, chloride, nitrite, nitrate, and orthophosphate in the Scituate Reservoir drainage area, Rhode Island, from October 1, 2015, through September 30, 2016 


\section{Conversion Factors}

U.S. customary units to International System of Units

\begin{tabular}{lll}
\hline \multicolumn{1}{c}{ Multiply } & \multicolumn{1}{c}{ By } & \multicolumn{1}{c}{ To obtain } \\
\hline mile $(\mathrm{mi})$ & 1.609 & kilometer $(\mathrm{km})$ \\
square mile $\left(\mathrm{mi}^{2}\right)$ & 2.590 & square kilometer $\left(\mathrm{km}^{2}\right)$ \\
cubic foot per second $\left(\mathrm{ft}^{3} / \mathrm{s}\right)$ & 0.02832 & cubic meter per second $\left(\mathrm{m}^{3} / \mathrm{s}\right)$ \\
ton, short $(2,000 \mathrm{lb})$ & 0.9072 & metric ton $(\mathrm{t})$ \\
\hline
\end{tabular}

\section{Datum}

Horizontal coordinate information is referenced to North American Datum of 1983 (NAD 83).

\section{Supplemental Information}

Concentrations of chemical constituents in water are given in either milligrams per liter (mg/L) or colony forming units per 100 milliliters (CFU/100 mL).

Loads of chemical constituents in water are given in kilograms $(\mathrm{kg})$, and daily loads are given in grams per day $(\mathrm{g} / \mathrm{d})$, kilograms per day $(\mathrm{kg} / \mathrm{d})$, kilograms per year $(\mathrm{kg} / \mathrm{yr})$, or million colony forming units per day (MCFU/d).

Yields are given in grams per day per square mile $\left(\mathrm{g} / \mathrm{d} / \mathrm{mi}^{2}\right)$, kilograms per day per square mile $\left(\mathrm{kg} / \mathrm{d} / \mathrm{mi}^{2}\right)$, kilograms per year per square mile $\left(\mathrm{kg} / \mathrm{yr} / \mathrm{mi}^{2}\right)$, or million colony forming units per day per square mile (MCFU/d/mi²).

\section{Abbreviations}

$\begin{array}{ll}\text { E. coli } & \text { Escherichia coli } \\ \text { MOVE.1 } & \text { Maintenance of Variance Extension type 1 } \\ \text { NWIS } & \text { National Water Information System } \\ \text { PWSB } & \text { Providence Water Supply Board } \\ \text { RIDEM } & \text { Rhode Island Department of Environmental Management } \\ \text { USGS } & \text { U.S. Geological Survey } \\ \text { WY } & \text { water year }\end{array}$





\title{
Streamflow, Water Quality, and Constituent Loads and Yields, Scituate Reservoir Drainage Area, Rhode Island, Water Year 2016
}

\author{
By Kirk P. Smith
}

\section{Abstract}

As part of a long-term cooperative program to monitor water quality within the Scituate Reservoir watershed, the U.S. Geological Survey in cooperation with the Providence Water Supply Board collected streamflow and water-quality data at the Scituate Reservoir and tributaries. Streamflow and concentrations of chloride and sodium estimated from records of specific conductance were used to calculate loads of chloride and sodium during water year (WY) 2016 (October 1, 2015, through September 30, 2016) for tributaries to the Scituate Reservoir, Rhode Island. Streamflow was measured or estimated by the U.S. Geological Survey following standard methods at 23 streamgages; 14 of these streamgages are equipped with instrumentation capable of continuously monitoring water level, specific conductance, and water temperature. Water-quality samples were collected by the Providence Water Supply Board at 34 sampling stations that also include 14 continuous-record streamgages maintained by the U.S. Geological Survey during WY 2016 as part of a long-term sampling program; all stations are in the Scituate Reservoir drainage area. Water-quality data collected by the Providence Water Supply Board are summarized by using values of central tendency and are used, in combination with measured (or estimated) streamflows, to calculate loads and yields (loads per unit area) of selected water-quality constituents for WY 2016.

The largest tributary to the reservoir, the Ponaganset River, which was monitored by the U.S. Geological Survey, contributed a mean streamflow of 18 cubic feet per second to the reservoir during WY 2016. For the same period, annual mean streamflows measured (or estimated) for the other monitoring stations in this study ranged from about 0.27 to about 12 cubic feet per second. Together, tributaries equipped with instrumentation capable of continuously monitoring specific conductance transported about 2,100,000 kilograms of chloride and 1,300,000 kilograms of sodium to the Scituate Reservoir during WY 2016; chloride and sodium yields for the tributaries ranged from 14,000 to 95,000 kilograms per square mile and from 8,600 to 56,000 kilograms per square mile, respectively.

\begin{abstract}
At the stations where water-quality samples were collected by the Providence Water Supply Board, the medians of the median concentrations were 27.9 milligrams per liter for chloride, 0.002 milligram per liter as nitrogen for nitrite, 0.13 milligram per liter as nitrogen for nitrate, 0.07 milligram per liter as phosphate for orthophosphate, and 700 and 10 colony forming units per 100 milliliters for total coliform bacteria and Escherichia coli (E. coli), respectively. The medians of the median daily loads of chloride, nitrite nitrogen, nitrate nitrogen, orthophosphate, and total coliform and $E$. coli bacteria were 170 kilograms per day, 8.9 grams per day, 570 grams per day, 320 grams per day, 41,000 million colony forming units per day, and 680 million colony forming units per day. The medians of the median yields of chloride, nitrite nitrogen, nitrate nitrogen, orthophosphate, total coliform, and $E$. coli bacteria were 53 kilograms per day per square mile, 4.7 grams per day per square mile, 130 grams per day per square mile, 165 grams per day per square mile, 23,000 million colony forming units per day per square mile, and 340 million colony forming units per day per square mile, respectively.
\end{abstract}

\section{Introduction}

The Scituate Reservoir is the primary source of drinking water for more than 60 percent of the population of Rhode Island. The Scituate Reservoir drainage area consists of six subbasins and covers an area of about 94 square miles in parts of the towns of Cranston, Foster, Glocester, Johnston, and Scituate, Rhode Island (fig. 1). Information about the water quality of the reservoir and its tributaries is important for management of the water supply and for the protection of human health. The Providence Water Supply Board (PWSB), the agency responsible for the management and distribution of the Scituate Reservoir water supply, has been monitoring and assessing water quality in the reservoir and reservoir drainage area for more than 60 years.

Since 1993, the U.S. Geological Survey (USGS) has been cooperating with the PWSB and the Rhode Island Department of Environmental Management (RIDEM) to measure 


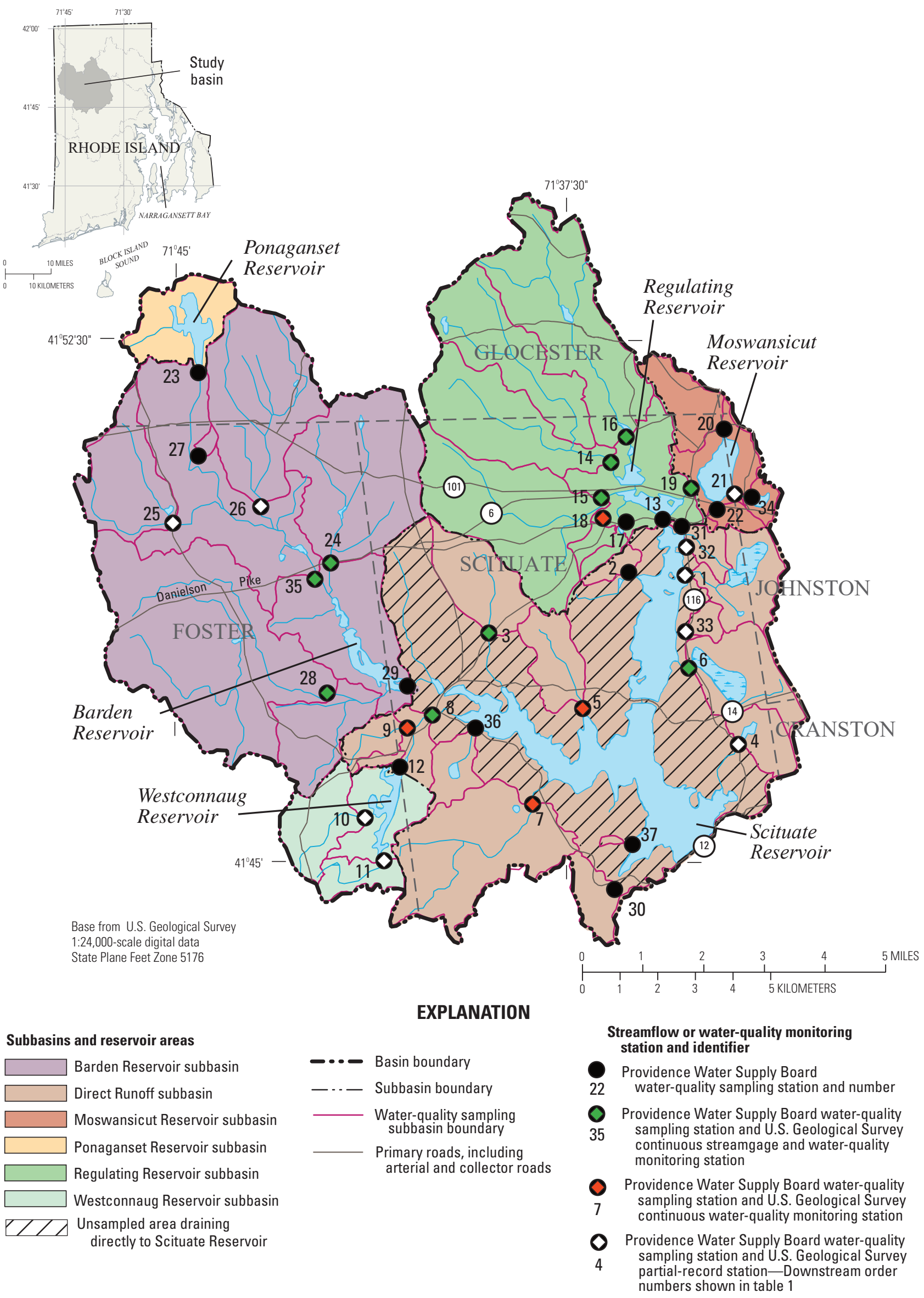

Figure 1. Locations of tributary-reservoir subbasins and stations in the Scituate Reservoir drainage area, Rhode Island, in water year 2016. 
streamflow in tributaries to the Scituate Reservoir. Streamflow has been continuously measured at 10 streamgages in the drainage area (table 1) since 2009 by the USGS. Streamflow also was continuously measured at four streamgages during 2009-14 and periodically measured at nine additional streamgages on tributaries in the drainage area. At the 13 streamgages without continuous flow data (partial-record streamgages; table 1), daily mean ${ }^{1}$ streamflow has been estimated by using methods developed by the USGS (Hirsch, 1982). The USGS also has been continuously measuring specific conductance at 14 monitoring stations since 2009 (table 1). Equations that relate specific conductance to concentrations of chloride and sodium in stream water were developed as part of previous cooperative studies of the USGS and PWSB (Nimiroski and Waldron, 2002; Smith, 2015b, 2018a). These equations used together with measured (or estimated) streamflows allow for nearly continuous estimation of chloride and sodium loads to the reservoir.

In 2016, the PWSB regularly, either monthly or quarterly, collected water-quality samples from 34 tributaries within the Scituate Reservoir drainage area. Compiled and tabulated streamflow (measured or estimated by the USGS) and waterquality data (collected by the PWSB) have been published in Breault and others (2000), Nimiroski and others (2008), Breault (2010), Breault and Campbell (2010a-d), Breault and Smith (2010), Smith and Breault (2011), Smith (2013, 2014, 2015a,b, 2016, 2018a-c).

This report presents data on streamflow, water quality, and loads and yields of selected constituents for water year $(W Y)^{2} 2016$ in the Scituate Reservoir drainage area. These data were collected as part of studies done by the USGS in cooperation with the PWSB and the RIDEM. A summary of measured and estimated streamflows is presented for the 10 continuous-record and 13 partial-record streamgages in the drainage area. Estimated monthly and annual loads and yields of chloride and sodium are presented for the 14 streamgages at which specific conductance is continuously monitored by the USGS. Summary statistics for water-quality data collected by the PWSB for 34 of the 37 sampling stations (table 1) during WY 2016 also are presented, and these data were used to calculate loads and yields of selected water-quality constituents.

\section{Streamflow Data Collection and Estimation}

Streamflow was measured or estimated by the USGS at 23 streamgages (table 1). Measured and estimated streamflows are necessary to estimate water volume and water-quality constituent loads and yields from tributary basins. Stream

\footnotetext{
${ }^{1}$ The arithmetic mean of the individual daily mean discharges for the year noted or for the designated period.

${ }^{2} \mathrm{~A}$ water year is the period between October 1 and September 30 and is designated by the year in which it ends.
}

stage was measured every 10 minutes at most continuousrecord streamgages. Streamflow was computed with a stagedischarge relation (known as a rating), which was developed on the basis of periodic manual measurements of streamflow. Daily mean streamflow at a streamgage was calculated by dividing the total volume of water that passed the streamgage each day by 86,400 (the number of seconds in a day).

Periodic manual streamflow measurements at partial-record streamgages were used concurrently with continuous-record measurements from streamgages in nearby hydrologically similar drainage areas to estimate a continuous daily record at the partial-record streamgages. Specifically, continuousstreamflow records for the 13 partial-record sites in the Scituate Reservoir drainage area (table 1) were estimated by using the Maintenance of Variance Extension type 1 (MOVE.1) method, as described by Ries and Friesz (2000) and Smith (2015b); data needed to estimate streamflows at partial-record sites were retrieved from the USGS National Water Information System (NWIS; U.S. Geological Survey, 2016). The upper and lower 90-percent confidence limits for the estimated mean annual streamflows, as described by Tasker and Driver (1988), are listed in table 2. These data indicate that there is a 90 -percent chance that the estimated mean annual streamflow is between the upper and lower 90-percent confidence limits.

Continuous-record streamgages were operated and maintained by the USGS during WY 2016 in cooperation with RIDEM (USGS streamgage 01115187) and the PWSB (fig. 1; table 1). Streamflow data for these streamgages were collected at 10- or 15-minute intervals (near-real-time streamflow data), were updated at 1-hour intervals on the internet, and are available through the NWIS web interface (U.S. Geological Survey, 2016). Error associated with measured streamflows was generally within about 15 percent as noted in the annual water year summary for each USGS streamgage.

\section{Water-Quality Data Collection and Analysis}

Water-quality data were collected by the USGS and the PWSB. Concentrations of sodium and chloride were estimated by the USGS from continuous records of specific conductance from 14 of the 21 streamgages. Water-quality samples were collected monthly or quarterly at 34 sampling stations in the Scituate Reservoir drainage area by the PWSB during WY 2016 as part of a long-term sampling program (table 1).

\section{Data Collected by the U.S. Geological Survey}

The USGS collected and analyzed specific conductance data at the 14 continuous-record streamgages (fig. 1; table 1). Measurements of specific conductance were recorded automatically at 10 - or 15-minute intervals at each streamgage. 
Table 1. Providence Water Supply Board water-quality sampling stations, water-quality samples, and available streamflow and specific conductance monitoring in the Scituate Reservoir drainage area, Rhode Island, from October 1, 2015, to September 30, 2016.

[Alternate station names are listed in parentheses for stations where different historical names were used for the same sampling location by the Providence Water Supply Board (PWSB). Locations of stations are shown on figure 1. USGS, U.S. Geological Survey; mi², square mile; QW, water quality; Na, sodium; Cl, chloride; M, monthly; Q, quarterly; Y, yes; N, no; Continuous, recorded at 10- or 15-minute intervals; --, none]

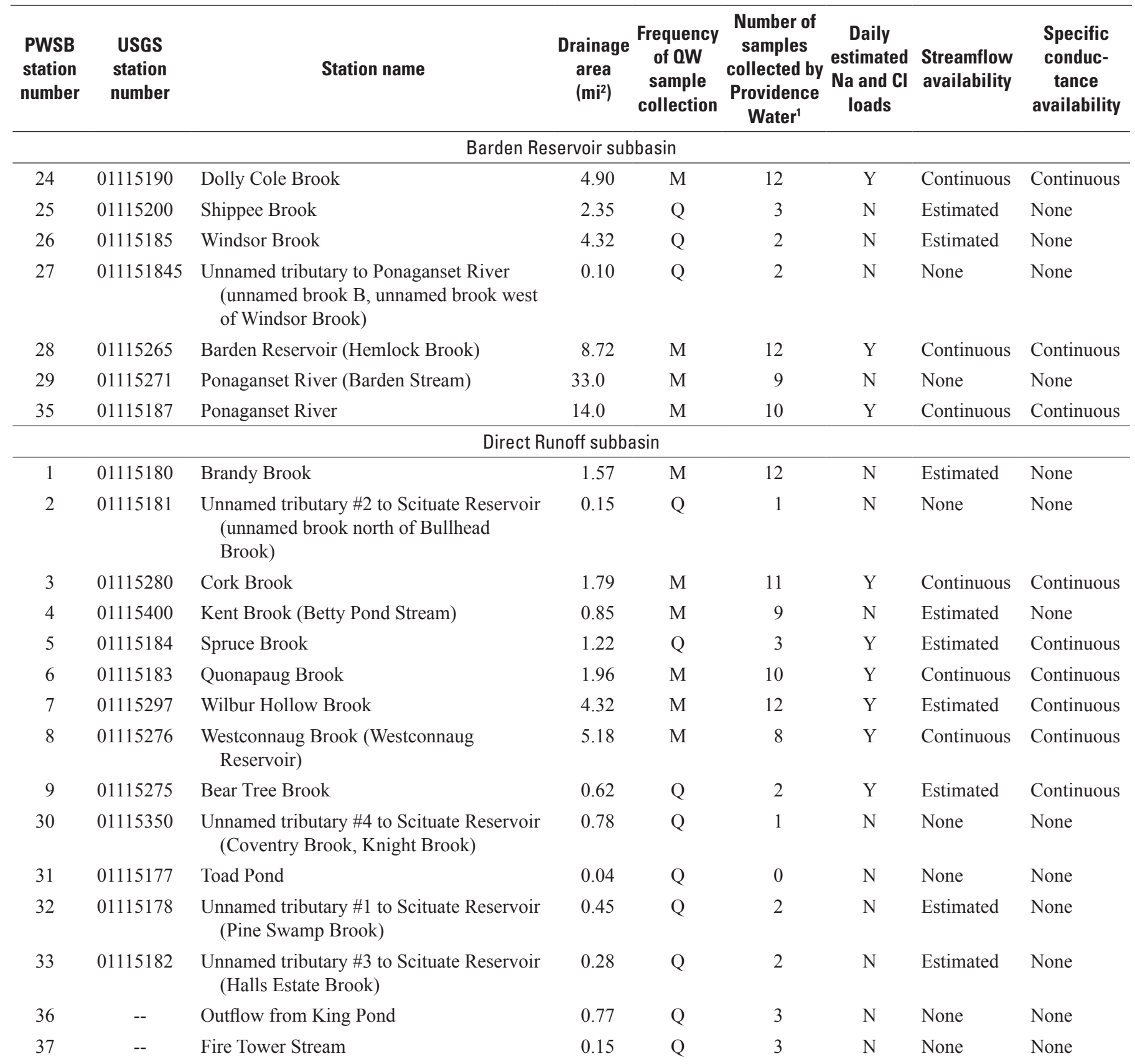


Table 1. Providence Water Supply Board water-quality sampling stations, water-quality samples, and available streamflow and specific conductance monitoring in the Scituate Reservoir drainage area, Rhode Island, from October 1, 2015, to September 30, 2016. -Continued

[Alternate station names are listed in parentheses for stations where different historical names were used for the same sampling location by the Providence Water

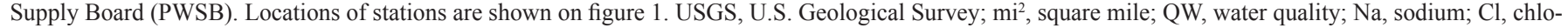
ride; $\mathrm{M}$, monthly; Q, quarterly; $\mathrm{Y}$, yes; N, no; Continuous, recorded at 10- or 15-minute intervals; --, none]

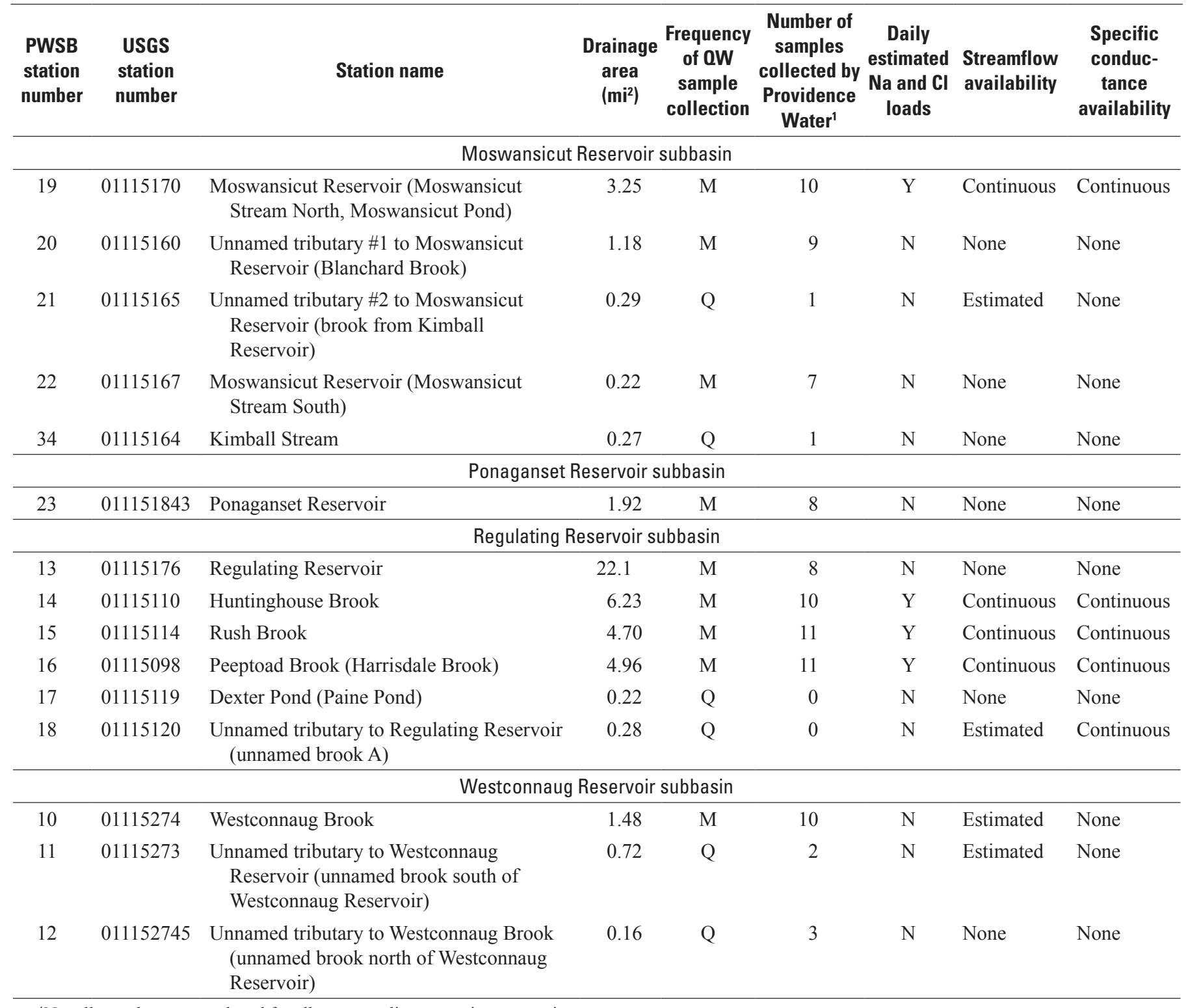

\footnotetext{
${ }^{1}$ Not all samples were analyzed for all water-quality properties or constituents.
} 
Table 2. Measured or estimated annual mean streamflow for tributary streams in the Scituate Reservoir drainage area, Rhode Island, from October 1, 2015, through September 30, 2016.

[Alternate station names are listed in parentheses for stations where different historical names were used for the same sampling location by the Providence Water Supply Board (PWSB). Locations of stations are shown on figure 1. USGS, U.S. Geological Survey; $\mathrm{ft}^{3} / \mathrm{s}$, cubic foot per second; $\mathrm{ft}^{3} / \mathrm{s} / \mathrm{mi}^{2}$, cubic foot per second per square mile]

\begin{tabular}{|c|c|c|c|c|c|c|}
\hline $\begin{array}{l}\text { PWSB } \\
\text { station } \\
\text { number }\end{array}$ & $\begin{array}{l}\text { USGS } \\
\text { station } \\
\text { number }\end{array}$ & Station name & $\begin{array}{c}\text { Annual mean } \\
\text { streamflow } \\
\left(\mathrm{ft}^{3} / \mathrm{s}\right)\end{array}$ & $\begin{array}{c}\text { Upper } \\
90-\text { percent } \\
\text { confidence } \\
\text { interval } \\
\left(\mathrm{ft}^{3} / \mathrm{s}\right)\end{array}$ & $\begin{array}{c}\text { Lower } \\
\text { 90-percent } \\
\text { confidence } \\
\text { interval } \\
\left(\mathrm{ft}^{3} / \mathrm{s}\right)\end{array}$ & $\begin{array}{c}\text { Annual mean } \\
\text { streamflow } \\
\left(\mathrm{ft}^{3} / \mathrm{s} / \mathrm{mi}^{2}\right)\end{array}$ \\
\hline \multicolumn{7}{|c|}{ Barden Reservoir subbasin } \\
\hline 24 & 01115190 & Dolly Cole Brook & 6.0 & 6.8 & 5.2 & 1.2 \\
\hline 26 & 01115185 & Windsor Brook & 5.4 & 22 & 1.3 & 1.2 \\
\hline 28 & 01115265 & Barden Reservoir (Hemlock Brook) & 12 & 14 & 11 & 1.4 \\
\hline 35 & 01115187 & Ponaganset River & 18 & 20 & 16 & 1.3 \\
\hline \multicolumn{7}{|c|}{ Direct Runoff subbasin } \\
\hline 1 & 01115180 & Brandy Brook & 1.8 & 3.3 & 1.0 & 1.2 \\
\hline 6 & 01115183 & Quonapaug Brook & 2.7 & 3.0 & 2.4 & 1.4 \\
\hline 7 & 01115297 & Wilbur Hollow Brook & 5.7 & 11 & 3.0 & 1.3 \\
\hline 8 & 01115276 & Westconnaug Brook (Westconnaug Reservoir) & 6.8 & 7.5 & 6.2 & 1.3 \\
\hline 9 & 01115275 & Bear Tree Brook & 1.1 & 2.0 & 0.67 & 1.9 \\
\hline 32 & 01115178 & $\begin{array}{l}\text { Unnamed tributary \#1 to Scituate Reservoir } \\
\text { (Pine Swamp Brook) }\end{array}$ & 0.45 & 0.89 & 0.22 & 1.0 \\
\hline 33 & 01115182 & $\begin{array}{l}\text { Unnamed tributary \#3 to Scituate Reservoir } \\
\text { (Halls Estate Brook) }\end{array}$ & 0.27 & 0.77 & 0.10 & 0.97 \\
\hline \multicolumn{7}{|c|}{ Moswansicut Reservoir subbasin } \\
\hline 14 & 01115110 & Huntinghouse Brook & 7.6 & 8.7 & 6.4 & 1.2 \\
\hline 15 & 01115115 & Rush Brook & 6.0 & 7.0 & 5.0 & 1.3 \\
\hline 16 & 01115098 & Peeptoad Brook (Harrisdale Brook) & 6.7 & 7.6 & 5.7 & 1.3 \\
\hline 18 & 01115120 & $\begin{array}{l}\text { Unnamed tributary to Regulating Reservoir } \\
\text { (unnamed brook A) }\end{array}$ & 0.36 & 1.5 & 0.09 & 1.3 \\
\hline \multicolumn{7}{|c|}{ Westconnaug Reservoir subbasin } \\
\hline 10 & 01115274 & Westconnaug Brook & 1.6 & 2.8 & 0.87 & 1.0 \\
\hline 11 & 01115273 & $\begin{array}{l}\text { Unnamed tributary to Westconnaug Reservoir } \\
\text { (unnamed brook south of Westconnaug Reservoir) }\end{array}$ & 0.93 & 1.6 & 0.54 & 1.3 \\
\hline
\end{tabular}


Measurements were made by using an instream probe and standard USGS methods for continuous water-quality monitoring at streams (Wagner and others, 2006). The specific conductance measurement data are available through the NWIS web interface (U.S. Geological Survey, 2016).

Concentrations of chloride and sodium were estimated from continuous measurements of specific conductance by using equations that were developed by the USGS to relate specific conductance to concentrations of chloride and sodium, as follows:

$$
\begin{gathered}
C_{C l}=S P C^{m} \times b \text { and } \\
C_{N a}=S P C^{m} \times b,
\end{gathered}
$$

where

$$
\begin{aligned}
& C_{\mathrm{Cl}} \text { is the chloride concentration, in milligrams } \\
& \text { per liter; } \\
& C_{\mathrm{Na}} \text { is the sodium concentration, in milligrams per } \\
& \text { liter; }
\end{aligned}
$$

\begin{tabular}{|c|c|c|c|c|c|c|c|c|c|}
\hline \multirow[b]{2}{*}{$\begin{array}{l}\text { PWSB } \\
\text { station } \\
\text { number }\end{array}$} & \multirow[b]{2}{*}{$\begin{array}{l}\text { USGS } \\
\text { station } \\
\text { number }\end{array}$} & \multicolumn{2}{|c|}{ Samples used in analyses } & \multicolumn{3}{|c|}{ Chloride } & \multicolumn{3}{|c|}{ Sodium } \\
\hline & & $\begin{array}{l}\text { Sample data range } \\
\text { (month/day/year) }\end{array}$ & $\begin{array}{c}\text { Sample } \\
\text { count }\end{array}$ & Slope & Intercept & $\begin{array}{c}\text { Standard error } \\
\text { of regressions } \\
\text { (percent) }\end{array}$ & Slope & Intercept & $\begin{array}{c}\text { Standard error } \\
\text { of regressions } \\
\text { (percent) }\end{array}$ \\
\hline 24 & 01115190 & $\begin{array}{l}03 / 08 / 2000 ; 03 / 29 / 2005 \\
01 / 22 / 2009 \text { to } 07 / 06 / 2017\end{array}$ & 26 & 1.2571 & 0.06894 & 3.8 & 1.2244 & 0.04913 & 7.3 \\
\hline 28 & 01115265 & $\begin{array}{l}03 / 28 / 2001 ; 03 / 30 / 2005 \\
01 / 22 / 2009 \text { to } 07 / 06 / 2017\end{array}$ & 26 & 1.2270 & 0.07901 & 5.5 & 1.1326 & 0.07443 & 9.0 \\
\hline 35 & 01115187 & $\begin{array}{l}03 / 28 / 2001 ; 03 / 29 / 2005 \\
01 / 22 / 2009 \text { to } 07 / 06 / 2017\end{array}$ & 26 & 1.2428 & 0.07282 & 6.3 & 1.1751 & 0.06094 & 8.4 \\
\hline 3 & 01115280 & $\begin{array}{l}03 / 08 / 2000 ; 03 / 30 / 2005 \\
01 / 22 / 2009 \text { to } 07 / 19 / 2017\end{array}$ & 26 & 1.2217 & 0.07704 & 4.9 & 1.0722 & 0.09611 & 7.8 \\
\hline 5 & 01115184 & $03 / 05 / 2009$ to $07 / 20 / 2017$ & 23 & 1.2558 & 0.06221 & 6.5 & 1.0813 & 0.08318 & 6.1 \\
\hline 8 & 01115276 & $01 / 22 / 2009$ to $07 / 19 / 2017$ & 23 & 1.1016 & 0.13513 & 4.9 & 1.0463 & 0.10969 & 5.9 \\
\hline 9 & 01115275 & $\begin{array}{l}03 / 08 / 2000 ; 03 / 30 / 2005 \\
01 / 22 / 2009 \text { to } 07 / 20 / 2017\end{array}$ & 25 & 1.0600 & 0.17564 & 4.2 & 1.0734 & 0.09639 & 5.6 \\
\hline 19 & 01115170 & $\begin{array}{l}03 / 08 / 2000 ; 03 / 29 / 2005 \\
01 / 22 / 2009 \text { to } 07 / 20 / 2017\end{array}$ & 29 & 1.2410 & 0.06537 & 4.0 & 1.1927 & 0.04976 & 4.7 \\
\hline 14 & 01115110 & $\begin{array}{l}03 / 28 / 2001 ; 03 / 29 / 2005 \\
01 / 22 / 2009 \text { to } 07 / 19 / 2017\end{array}$ & 30 & 1.2030 & 0.07202 & 12 & 1.0670 & 0.07766 & 11 \\
\hline 15 & 01115114 & $01 / 22 / 2009$ to $07 / 20 / 2017$ & 31 & 1.1748 & 0.09355 & 4.0 & 1.0885 & 0.08810 & 7.5 \\
\hline
\end{tabular}

These regression equations were developed by using the MOVE. 1 method (also known as the line of organic correlation; Helsel and Hirsch, 2002) on the basis of concurrent

Table 3. Regression equation coefficients used to estimate concentrations of chloride and sodium from values of specific conductance for U.S. Geological Survey monitoring stations in the Scituate Reservoir drainage area, Rhode Island, from October 1, 2015, through September 30, 2016.

[Locations of stations are shown on figure 1. U.S. Geological Survey (USGS) parameter codes: specific conductance, 90095; chloride, 00940 ; sodium, 00930. PWSB, Providence Water Supply Board] 
measurements of specific conductance ${ }^{3}$ along with chloride ${ }^{4}$ and sodium ${ }^{5}$ concentrations measured in water-quality samples collected by the USGS from tributaries in the Scituate Reservoir drainage area (U.S. Geological Survey, 2016).

MOVE. 1 was chosen for regression analysis to maintain variance (Hirsch and Gilroy, 1984). Some missing values of specific conductance were estimated. In these cases, values of specific conductance were estimated by proportional distribution between recorded values.

\section{Data Collected by the Providence Water Supply Board}

Water-quality samples were collected by the PWSB at 34 of the 37 fixed stations on tributaries draining to the Scituate Reservoir during WY 2016. Sampling visits typically are conducted monthly at 19 stations and quarterly at another 15 stations (table 1). No quarterly water samples were collected at Toad Pond (PWSB station 31), Dexter Pond (PWSB station 17), and unnamed tributary to Regulating Reservoir (PWSB station 18) during WY 2016.

Water-quality samples were not collected during specific weather conditions; instead, a strictly periodic water-quality sampling schedule was followed so that water-quality samples would be representative of various weather conditions.

${ }^{3}$ Specific conductance is USGS parameter code 90095.

${ }^{4}$ Chloride is USGS parameter code 00940.

${ }^{5}$ Sodium is USGS parameter code 00930.
However, sometimes samples could not be collected because tributaries at the sampling stations were dry or frozen. When possible, water-quality samples were collected by dipping the sample bottle into the tributary at the center of flow (Richard Blodgett, PWSB, written commun., 2005). Samples were transported on ice to the PWSB water-quality laboratory at the P.J. Holton Water Purification Plant in Scituate. Waterquality properties and constituent concentrations were measured by using unfiltered water samples. These waterquality properties included $\mathrm{pH}$, alkalinity, color, turbidity, and concentrations of chloride, nitrite, nitrate, orthophosphate, and bacteria (Escherichia coli [E. coli] and total coliform); the data are published in Smith (2018c). Analytical methods used for the determination of values or concentrations of $\mathrm{pH}$, color, turbidity, alkalinity, and chloride are documented by Eaton and others (2017). Concentrations of nitrite and nitrate were determined by U.S. Environmental Protection Agency method 353.2 (U.S. Environmental Protection Agency, 1993). Concentrations of orthophosphate were determined by the Hach PhosVer Method (Hach Method 8048; Hach Company, 2000). Before August 2016, Standard Method 9222 was used for the determination of concentrations of bacteria in water samples, and thereafter, Standard Method 9223 was used for the determination of concentrations of bacteria (Eaton and others, 2017).

Water-quality samples were collected by the PWSB during a wide range of flow conditions. The daily mean flow-duration curve for Rush Brook near Elmdale Road near North Scituate (USGS streamgage 01115114) for WY 2016 is shown in figure 2 . The curve represents the percentage

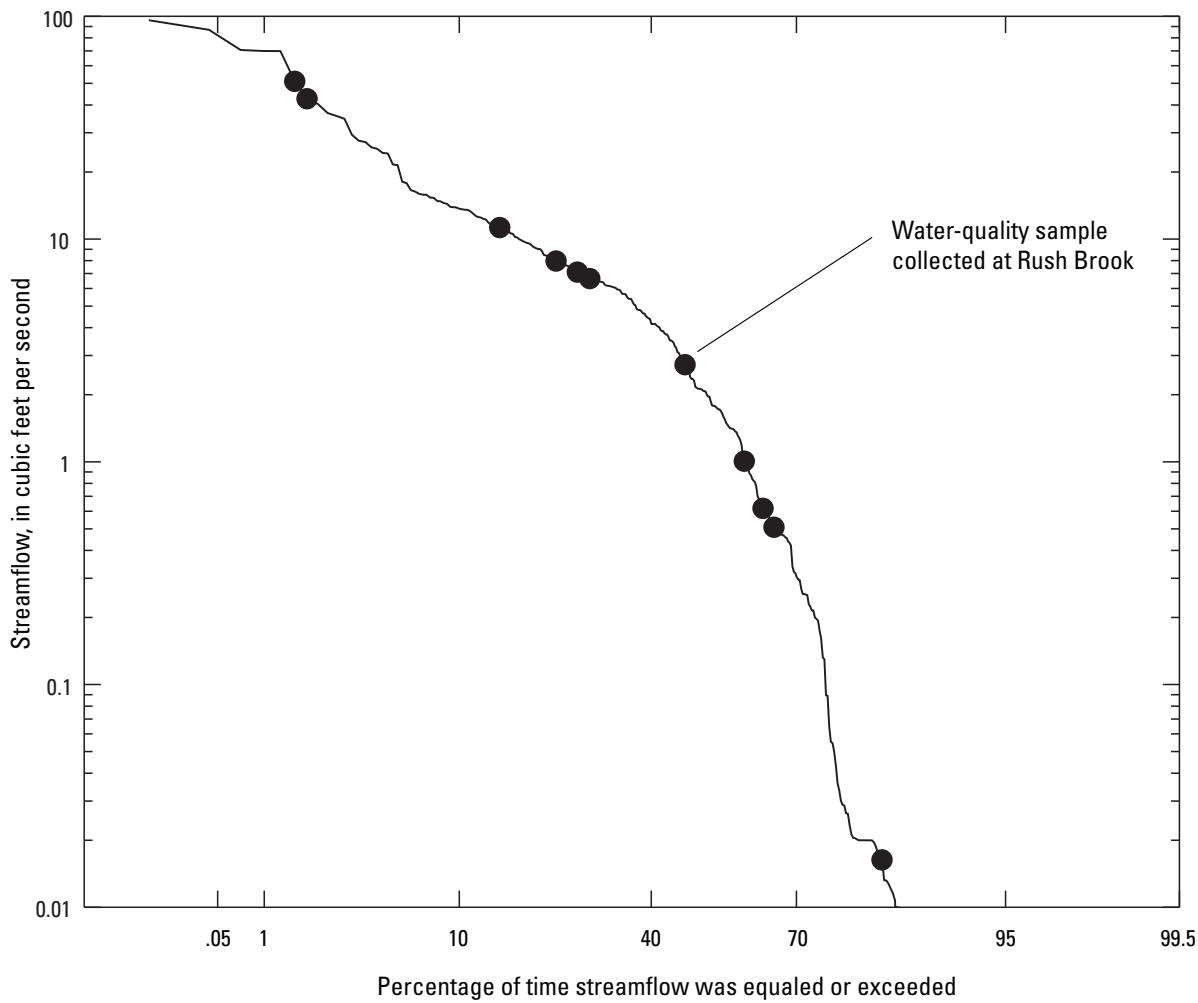

Figure 2. Flow-duration curve and streamflow on the dates (represented by points) when water-quality samples were collected for the U.S. Geological Survey continuous streamgage on Rush Brook near Elmdale Road North Scituate (01115114), Rhode Island, in water year 2016. Location of station is shown on figure 1. 
of time that each flow duration was equaled or exceeded at this station; the flows at this station on days when waterquality samples were collected are represented by the plotted points superimposed on the curve. Samples were collected at flow durations ranging from the 1.5 percentile to the 84th percentile; this range indicates that the water-quality samples collected in WY 2016 represented a wide range of flow conditions during that water year. About 15 percent of the flows at this station were equal to or less than 0.01 cubic foot per second $\left(\mathrm{ft}^{3} / \mathrm{s}\right)$ during WY 2016.

\section{Estimating Daily, Monthly, and Annual Loads and Yields}

Daily, monthly, and annual chloride and sodium loads (in kilograms) were estimated for all streamgages for which continuous-streamflow and specific-conductance data were available for WY 2016. Daily flow-weighted concentrations of chloride and sodium were calculated by multiplying instantaneous flows by concurrent concentrations of chloride and sodium (estimated from measurements of specific conductance) for each day and dividing by the total flow for that day. At the four continuous monitoring stations, where instantaneous flow was unavailable (table 1), daily mean concentrations of chloride and sodium were calculated from the daily mean value of specific conductance for each day. The latter method may result in less accurate concentrations because instantaneous measurements of specific conductance may change (decrease or increase) with surface water runoff; however, the variability of instantaneous measurements of specific conductance at these streamgages was generally small and daily mean values did not differ substantially from daily flow-weighted values estimated during prior water years when instantaneous flow data were available. Daily loads of chloride and sodium were estimated by multiplying daily concentrations of chloride and sodium (in milligrams per liter) by daily discharge (in liters per day). Daily data were summed to estimate monthly or annual loads.

Daily loads of water-quality constituents (in samples collected by the PWSB) were calculated for all sampling dates during WY 2016 (table 4, in back of report) for which periodic- or continuous-streamflow data were available (table 1). These loads were calculated by multiplying constituent concentrations (in milligrams or colony forming units per liter) in single samples by the daily discharge (in liters per day) for the day on which each sample was collected. The flows, which in some cases were estimates, were assumed to be representative of the flow at the time of the sample collection. Loads (in million colony forming units, kilograms, or grams per day) and yields (in million colony forming units, kilograms, or grams per day per square mile) were calculated for bacteria, chloride, nitrite, nitrate, and orthophosphate. Censored data (concentrations reported as less than method detection limits) were replaced with concentrations equal to one-half the method detection limit.

\section{Streamflow}

Monitoring streamflow is a necessary step to measure the volume of water and estimate constituent loads to the Scituate Reservoir. The Ponaganset River is the largest monitored tributary to the Scituate Reservoir. Mean annual streamflow at the streamgage on the Ponaganset River (PWSB station 35; USGS streamgage 01115187) for the entire period of its operation (mean of the annual mean streamflows for the period of record, WY 1994-2015) before WY 2016 was about $29 \mathrm{ft}^{3} / \mathrm{s}$ (U.S. Geological Survey, 2016). During WY 2016, annual mean streamflow of $18 \mathrm{ft}^{3} / \mathrm{s}$ was lower than the mean of the annual mean streamflows for the period of record. Daily mean streamflow was often below the 10th percentile for the daily mean streamflows for the period of record (fig. 3) for much of September through December 2015 and for lesser periods through WY 2016 (fig. 3). Streamflow recovered to more typical rates of flow during the winter of WY 2016, with short periods exceeding the 90th percentile for the daily mean streamflows for the period of record later in WY 2016. Mean annual streamflow at the Peeptoad Brook streamgage (PWSB station 16, streamgage 01115098), the other longterm continuous-record streamgage in the Scituate Reservoir drainage area, for its period of record (WY 1994-2015) before WY 2016 was about $10.5 \mathrm{ft}^{3} / \mathrm{s}$ (U.S. Geological Survey, 2016). Annual mean streamflow at the Peeptoad Brook streamgage during WY 2016 also was lower at $6.7 \mathrm{ft}^{3} / \mathrm{s}$ than the mean annual streamflow for its period of record.

\section{Water Quality and Constituent Loads and Yields}

Water-quality conditions in the Scituate Reservoir drainage area are described by summary statistics for water-quality properties, constituent concentrations, and estimated constituent loads and yields. Loads and yields characterize the rates at which masses of constituents are transferred to the reservoir by tributaries. In the case of loads, tributaries with high flows tend to have high loads because the greater volume of water can carry more of the constituent to the reservoir per unit time than tributaries with low flows. Yields represent the constituent load per unit of drainage area and are calculated by dividing the load estimated for a streamgage by the drainage area for the monitoring station. Yields are useful for comparison among streamgages that have different drainage areas because the effects of basin size and therefore total streamflow volume are attenuated. Yields also are useful for examining potential differences among basin properties that may contribute to water quality in the reservoir. 


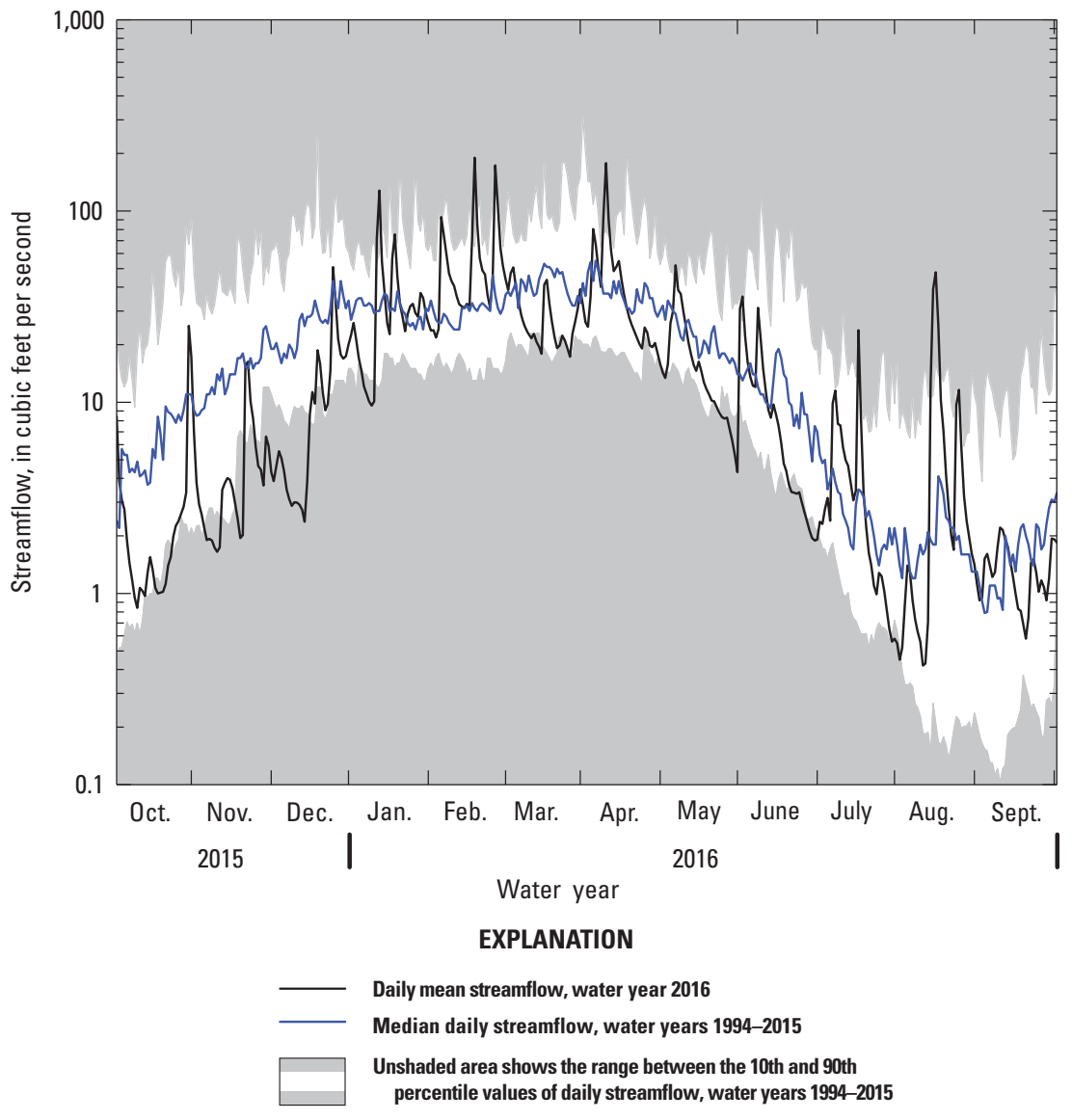

Figure 3. Measured daily mean streamflow for 0 ctober 1, 2015, through September 30, 2016, and the 10th percentile, median, and 90th percentile values of daily streamflow for October 1, 1994, through September 30, 2015, for the U.S. Geological Survey continuousrecord streamgage on the Ponaganset River at South Foster (01115187) in the Scituate Reservoir drainage area, Rhode Island. Location of station is shown on figure 1.
Summary statistics include means and medians. For some purposes, median values are more appropriate because they are less likely to be affected by high or low concentrations (or outliers). Medians are especially important to use for summarizing a relatively limited number of values. In contrast, continuously monitored streamflow and loads of chloride and sodium (estimated from measurements of specific conductance), which include a large number of values, are better summarized in terms of means because a large dataset is more resistant to the effects of outliers than small datasets. Mean values also are particularly appropriate for characterizing loads because outlier values, which typically represent large flows, are important to include in estimates of constituent masses delivered to receiving waters.

Uncertainties associated with measuring streamflow and specific conductance and with chloride and sodium sample collection, preservation, and analysis produce uncertainties in load and yield estimates. The load and yield estimates presented in the text and tables are the most likely values for chloride and sodium inputs from tributaries or their drainage basins, based on the available data and analysis methods. It may be best to discuss loads and yields in terms of a range within which the true values lie; however, the most probable values of loads and yields are presented for ease of discussion and presentation. The range within which the true values lie depends on the uncertainties in individual measurements of streamflow and concentration, which are difficult to quantify with available information. The uncertainties associated with streamflow are commonly assumed to affect load and yield calculations more than the errors associated with measuring specific conductance and (or) chemical analysis, and the uncertainties associated with estimated streamflow are greater than those associated with measured streamflow. The most probable values of loads and yields presented in the tables and text are sufficient for planning-level analysis of water quality in tributaries and their drainage basins.

\section{Chloride and Sodium Loads and Yields Estimated From Specific-Conductance Monitoring Data}

Chloride and sodium are constituents of special concern in the Scituate Reservoir drainage area; they are major constituents of road salt used for deicing, and several major roadways cross the drainage basin. State Routes 12 and 14 cut across the main body of the reservoir, and State Route 116 parallels the eastern limb (fig. 1). Nimiroski and Waldron (2002) indicated that tributaries in basins with State-maintained roads had substantially higher concentrations of chloride and sodium than tributaries in basins with low road density, presumably because of deicing activities. In addition, sodium is a constituent of potential concern for human health; some persons on restricted diets might need to limit intake of sodium. 
Estimated monthly mean ${ }^{6}$ chloride concentrations in tributaries of the Scituate Reservoir drainage area ranged from 9.3 to 97 milligrams per liter (mg/L), and estimated monthly mean sodium concentrations ranged from 6.2 to $59 \mathrm{mg} / \mathrm{L}$ (table 5). The highest monthly mean concentrations of chloride and sodium were estimated to be 97 and $59 \mathrm{mg} / \mathrm{L}$, respectively, at Quonapaug Brook (PWSB station 6) in October 2015 and 91 and $52 \mathrm{mg} / \mathrm{L}$, respectively, at Rush Brook (PWSB station 15) in September 2016. The estimated monthly mean concentrations at all stations were greater during summer and early fall compared with the estimated monthly mean concentrations during the winter months. The highest annual mean ${ }^{7}$ concentrations of chloride and sodium were estimated to be 57 and $34 \mathrm{mg} / \mathrm{L}$, respectively, at Bear Tree Brook (table 6). These high concentrations at Bear Tree Brook are the result of residual chloride and sodium leaching from a formerly uncovered salt storage pile to groundwater (Nimiroski and Waldron, 2002) and relatively small surfacewater flows. Annual mean concentrations of chloride and sodium estimated to be 54 and $31 \mathrm{mg} / \mathrm{L}$, respectively, at unnamed tributary to Regulating Reservoir and 53 and $31 \mathrm{mg} / \mathrm{L}$, respectively, at Moswansicut Reservoir also were relatively high (table 6). Both of these stations are located in the more developed, northeastern part of the Scituate Reservoir drainage area (fig. 1).

During WY 2016, the Scituate Reservoir received about 2,100,000 kilograms (kg; about 2,300 short tons) of chloride and $1,300,000 \mathrm{~kg}$ (about 1,400 short tons) of sodium from tributaries that are equipped with instrumentation capable of continuously monitoring specific conductance. The highest chloride and sodium loads in the drainage area during WY 2016 were estimated to be 380,000 and 230,000 kg, respectively, at the Ponaganset River station (PWSB station 35; table 6). Monthly estimated chloride and sodium loads were highest in February (table 7), except at Wilbur Hollow Brook (PWSB station 7) and Westconnaug Brook (PWSB station 8) where the monthly estimated loads were higher during April and at Peeptoad Brook (PWSB station 16) where the monthly estimated load was highest during January. Monthly estimated chloride and sodium loads for Quonapaug Brook (PWSB station 6) were the same in February and April. From January through April, the sum of the monthly loads of chloride and sodium at each station accounted for 69 percent of the annual load for the monitored area in the Scituate Reservoir drainage area. The highest annual chloride and sodium yields were 95,000 and 56,000 kilograms per square mile, respectively, measured at Bear Tree Brook (PWSB station 9; table 6). During WY 2016, estimated annual loads of chloride and sodium at the continuous monitoring stations were less than the median annual loads for WY 2009-15 at all stations except for Spruce Brook (PWSB station 5; chloride only), Quonapaug Brook (PWSB station 6), Westconnaug

\footnotetext{
${ }^{6}$ Monthly mean concentrations were calculated by dividing the total monthly load by the total discharge for the month.

${ }^{7}$ Annual mean concentrations were calculated by dividing the total annual load by the total discharge for the year.
}

Brook (PWSB station 8), and Bear Tree Brook (PWSB station 9) in the Direct Runoff subbasin and Peeptoad Brook (PWSB station 16) in the Regulating Reservoir subbasin (fig. 4).

\section{Physical and Chemical Properties and Daily Loads and Yields Estimated From Data Collected by the Providence Water Supply Board}

\section{Physical and Chemical Properties}

Physical and chemical properties, including $\mathrm{pH}$, turbidity, alkalinity, and color, were routinely measured to characterize water quality in each of the six subbasins in the Scituate Reservoir drainage area (table 8). Specifically, $\mathrm{pH}$ is a measure of the acidity of the water, color can be an indirect measure of the amount of organic carbon dissolved in the water column, turbidity is an indirect measure of suspended particles, and alkalinity is a measure of the acid-neutralizing capacity of water.

The median $\mathrm{pH}$ in tributaries in the Scituate Reservoir drainage area ranged from 5.3 to 7.0; the median of the medians for all stations was 6.3. Median values of color ranged from 12 to 140 platinum cobalt units; the median for all stations was 35 platinum cobalt units. Median values of turbidity ranged from 0.27 to 1.8 nephelometric turbidity units; the median for all stations was 0.62 nephelometric turbidity units. Median alkalinity values in tributaries were low, ranging from 2.3 to $15 \mathrm{mg} / \mathrm{L}$ as calcium carbonate $\left(\mathrm{CaCO}_{3}\right)$; the median for all stations was $4.8 \mathrm{mg} / \mathrm{L}$ as $\mathrm{CaCO}_{3}$ (table 8).

\section{Constituent Concentrations and Daily Loads and Yields}

Fecal indicator bacteria, chloride, and nutrients such as nitrogen and phosphorus are commonly detected in natural water; at elevated concentrations, these constituents can cause or contribute to water-quality impairments. Fecal indicator bacteria, which are found in the intestines of warm-blooded animals, may indicate impairment from sewage contamination or from livestock or wildlife that defecate in or near the stream margin. Chloride originates in tributary stream water from precipitation, weathering, or human activities such as waste disposal, use of septic systems, and road deicing. Sources of nutrients in tributary stream water include atmospheric deposition, leaching of naturally occurring organic material, discharge of groundwater that is enriched with nutrients from septic-system leachate, and runoff contaminated with fertilizer or animal waste. The ultimate intended use of water in the tributaries is drinking water, which must meet specific water-quality standards. For this reason, the PWSB and the USGS closely monitor concentrations of these constituents in tributaries. Median concentrations, loads, and yields of waterquality constituents are listed in tables 8 and 9. 


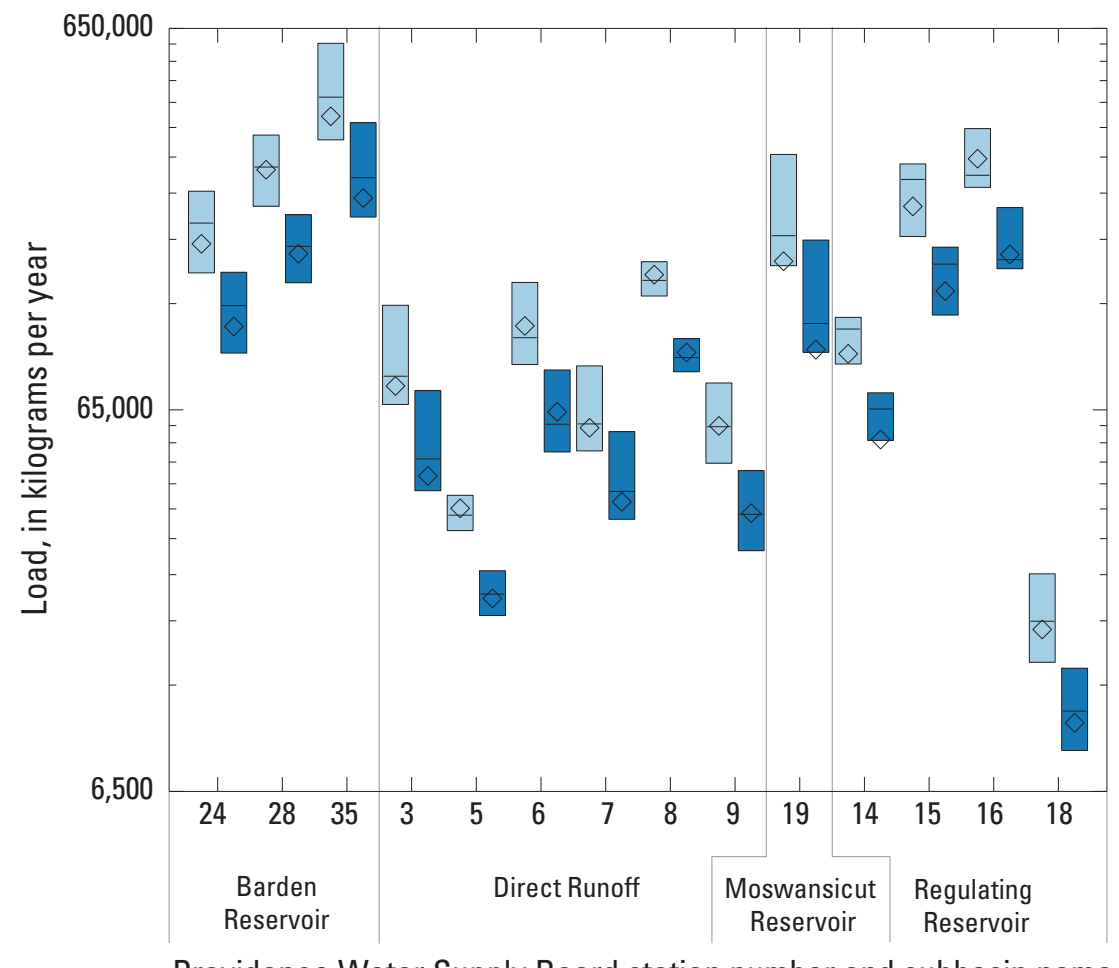

Providence Water Supply Board station number and subbasin name

\section{EXPLANATION}

Chloride load

Sodium load

Maximum annual load for water years 2009-15

Median annual load for water years 2009-15

Annual load for water year 2016

Minimum annual load for water years 2009-15
Figure 4. Annual loads of chloride and sodium estimated from streamflow and specific conductance data for water year 2016 and associated minimum, maximum, and median annual loads for water years 2009-15 at 14 Providence Water Supply Board stations in the Scituate Reservoir drainage area, Rhode Island. Location of stations shown on figure 1.

\section{Bacteria}

Median concentrations of total coliform bacteria were above the detection limit (10 colony forming units per 100 milliliters [CFU/100 mL]) at all sites (table 8); median concentrations of $E$. coli were equal to or greater than the detection limit of $10 \mathrm{CFU} / 100 \mathrm{~mL}$ before August 2016 and $1 \mathrm{CFU} / 100 \mathrm{~mL}$ thereafter at 14 of the 34 sites for which samples were collected. Total coliform bacteria concentrations were greater than $E$. coli concentrations (as expected because total coliform is more inclusive); the medians of median concentrations for all sites in the drainage area were $700 \mathrm{CFU} / 100 \mathrm{~mL}$ for total coliform bacteria and $10 \mathrm{CFU} / 100 \mathrm{~mL}$ for $E$. coli (table 8). The median concentration of total coliform bacteria was highest at unnamed tributary \#2 to Moswansicut Reservoir (PWSB station 21) at $8,400 \mathrm{CFU} / 100 \mathrm{~mL}$. The highest median concentration of E. coli (105 CFU/100 mL) was measured in samples collected at Quonapaug Brook (PWSB station 6) and Huntinghouse Brook (PWSB station 14). Median concentrations of fecal indicator bacteria were lowest at Kimball Stream (PWSB station 34). Median concentrations of $E$. coli were equivalent to or greater than $10 \mathrm{CFU} / 100 \mathrm{~mL}$ at more than half of the sampling stations.

Median daily loads and yields of total coliform bacteria and $E$. coli varied by about two orders of magnitude; the highest median daily yield of total coliform bacteria at 480,000 million colony forming units per day per square mile (MCFU/d $/ \mathrm{mi}^{2}$ ) and the highest median daily yield of E. coli of 4,500 MCFU/d/ $\mathrm{mi}^{2}$ were at unnamed tributary \#2 to Moswansicut Reservoir (PWSB station 21; table 9). Although relatively high for sampling stations in the Scituate Reservoir subbasin, median daily bacteria yields at Moswansicut Reservoir are low to moderate for yields of indicator bacteria in sewage-contaminated stream water or stream water affected by stormwater runoff in an urban environment 
(Breault and others, 2002). The median daily loads of total coliform bacteria for all subbasins in the Scituate Reservoir drainage area ranged from 730 to 350,000 million colony forming units per day (MCFU/d), and yields ranged from 860 to $480,000 \mathrm{MCFU} / \mathrm{d} / \mathrm{mi}^{2}$; E. coli loads ranged from less than 160 to $4,900 \mathrm{MCFU} / \mathrm{d}$, and yields ranged from 89 to 4,500 MCFU/d/mi² (table 9).

\section{Chloride and Sodium}

The highest median chloride concentration of $92.5 \mathrm{mg} / \mathrm{L}$ was measured in the Direct Runoff subbasin at unnamed tributary \#2 to Scituate Reservoir (PWSB station 2; table 8). Median daily chloride loads and yields estimated from samples collected by the PWSB varied among monitoring stations in the drainage area (table 9); the median daily chloride yield for monitored areas within the drainage area was 53 kilograms per day per square mile $\left(\mathrm{kg} / \mathrm{d} / \mathrm{mi}^{2}\right)$. Ponaganset River (PWSB station 35) had the largest median daily chloride load at 1,100 kilograms per day. The largest median daily chloride yield was determined to be $370 \mathrm{~kg} / \mathrm{d} / \mathrm{mi}^{2}$ at Bear Tree Brook (PWSB station 9). The estimated annual mean yields of chloride and sodium for the drainage areas above the 14 USGS continuous-record streamgages, which represent nearly 66 percent of the Scituate Reservoir drainage area, were 93 and $56 \mathrm{~kg} / \mathrm{d} / \mathrm{mi}^{2}$, respectively. These estimated annual mean yields of chloride and sodium for WY 2016 were about 13 percent lower than the estimated annual mean yields of 108 and $64 \mathrm{~kg} / \mathrm{d} / \mathrm{mi}^{2}$, respectively, for WY 2015 (Smith, 2018a).

\section{Nutrients}

Median concentrations of nitrite and nitrate (table 8 ) were 0.002 and $0.13 \mathrm{mg} / \mathrm{L}$ as nitrogen, respectively. The highest median concentration of nitrite nitrogen was $0.012 \mathrm{mg} / \mathrm{L}$ measured in a sample collected at Moswansicut Reservoir (PWSB station 22). The highest median concentration of nitrate nitrogen was $0.65 \mathrm{mg} / \mathrm{L}$ measured in a sample collected at unnamed tributary \#2 to Scituate Reservoir (PWSB station 2). The median concentration of orthophosphate for the entire study area (table 8 ) was $0.07 \mathrm{mg} / \mathrm{L}$ as phosphate $\left(\mathrm{PO}_{4}\right)$. The maximum median concentration of orthophosphate was $0.23 \mathrm{mg} / \mathrm{L}$ as $\mathrm{PO}_{4}$ measured in Kimball Stream (PWSB station 34). Median daily nitrite nitrogen and orthophosphate loads were largest at Ponaganset River (PWSB station 35) at 67 and 2,700 grams per day (g/d), respectively (table 9). Median daily nitrate nitrogen loads were largest at Bear Tree Brook (PWSB station 9) at 2,200 g/d. The largest median daily yields for nitrite and nitrate nitrogen were 9.9 and 3,500 grams per day per square mile $\left(\mathrm{g} / \mathrm{d} / \mathrm{mi}^{2}\right)$, respectively, at Bear Tree Brook. The largest median daily yield for orthophosphate was $660 \mathrm{~g} / \mathrm{d} / \mathrm{mi}^{2}$ at Pine Swamp Brook (PWSB station 32; table 9). The medians of median daily loads and yields were $8.9 \mathrm{~g} / \mathrm{d}$ and $4.7 \mathrm{~g} / \mathrm{d} / \mathrm{mi}^{2}$ for nitrite nitrogen, $570 \mathrm{~g} / \mathrm{d}$ and $130 \mathrm{~g} / \mathrm{d} / \mathrm{mi}^{2}$ for nitrate nitrogen, and $320 \mathrm{~g} / \mathrm{d}$ and $165 \mathrm{~g} / \mathrm{d} / \mathrm{mi}^{2}$ for orthophosphate. 


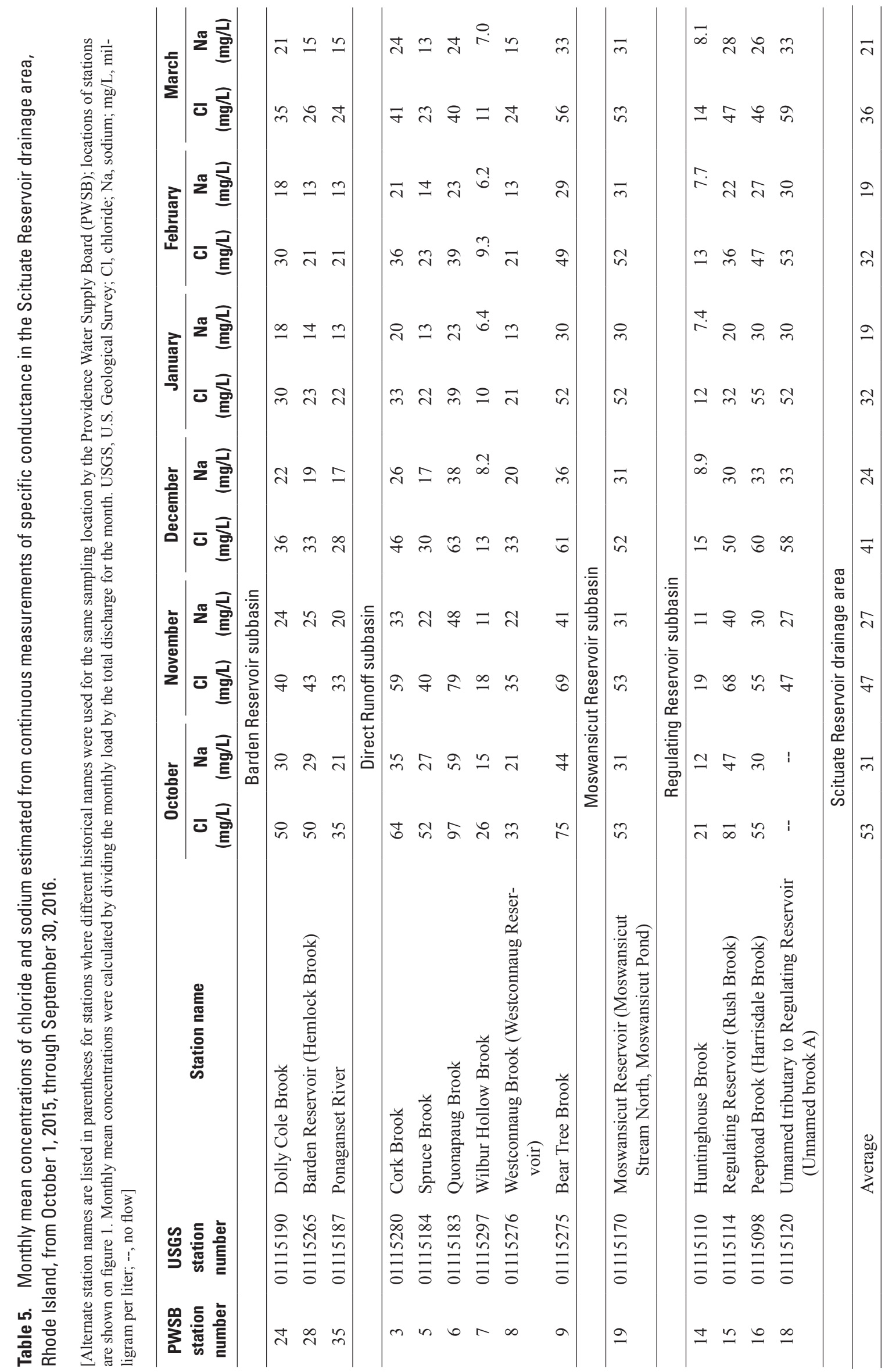




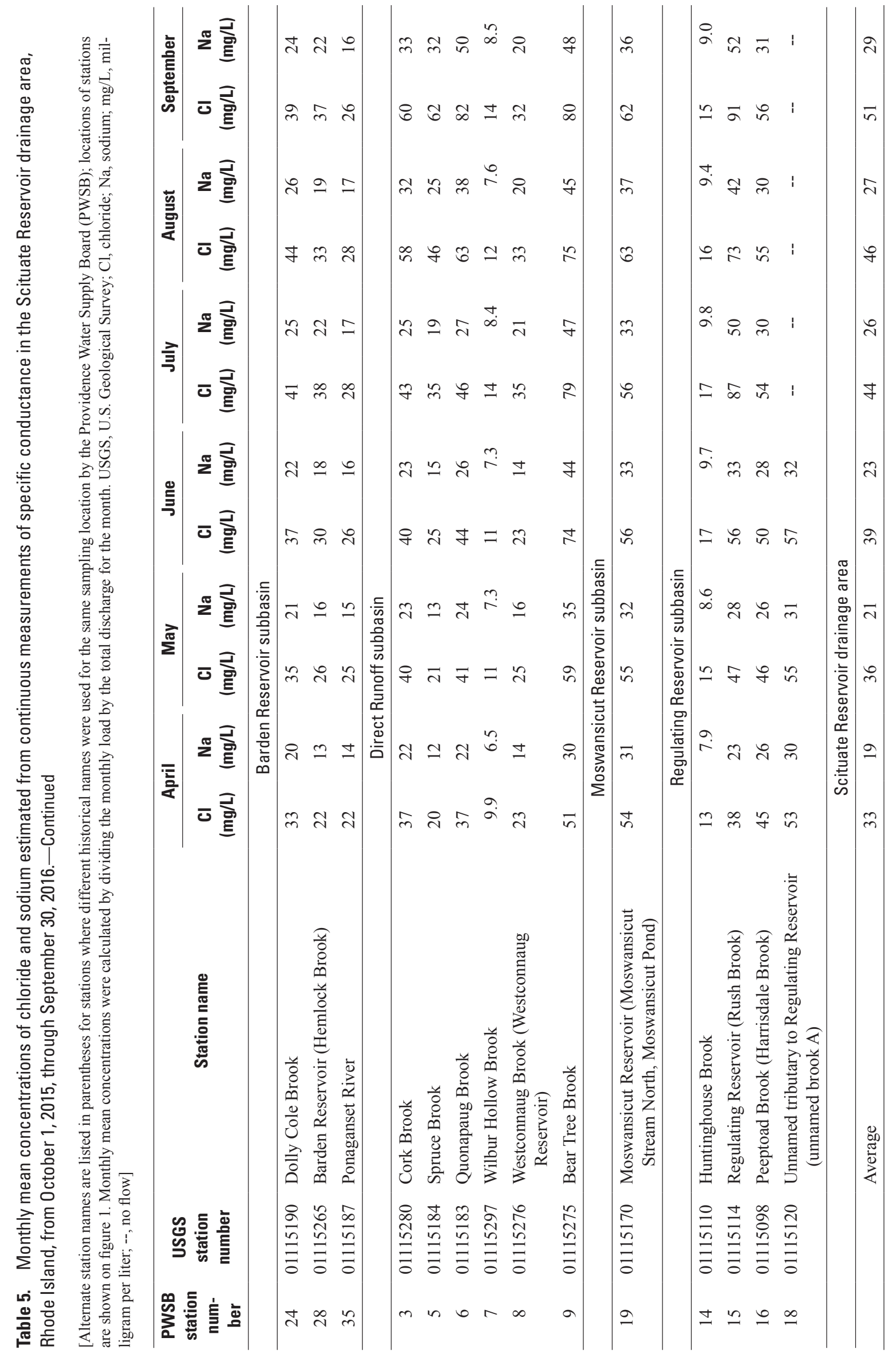


Table 6. Annual mean chloride and sodium concentrations, loads, and yields for sampling stations in the Scituate Reservoir drainage area, Rhode Island, from October 1, 2015, through September 30, 2016.

[Alternate station names are listed in parentheses for stations where different historical names were used for the same sampling location by the Providence Water Supply Board (PWSB). Locations of stations are shown on figure 1. Annual mean concentrations were calculated by dividing the annual load by the total discharge for the year; annual mean yields were calculated by dividing the sum of individual loads by the sum of the drainage area. USGS, U.S. Geological Survey; $\mathrm{Cl}$, chloride; $\mathrm{Na}$, sodium; $\mathrm{mg} / \mathrm{L}$, milligram per liter; $\mathrm{kg} / \mathrm{yr}$, kilogram per year; $\mathrm{kg} / \mathrm{yr} / \mathrm{mi}^{2}$, kilogram per year per square mile]

\begin{tabular}{|c|c|c|c|c|c|c|c|c|}
\hline \multirow{2}{*}{$\begin{array}{l}\text { PWSB } \\
\text { station } \\
\text { number }\end{array}$} & \multirow{2}{*}{$\begin{array}{l}\text { USGS } \\
\text { station } \\
\text { number }\end{array}$} & \multirow[b]{2}{*}{ Station name } & \multicolumn{2}{|c|}{ Concentration } & \multicolumn{2}{|c|}{ Load } & \multicolumn{2}{|c|}{ Yield } \\
\hline & & & $\underset{(\mathrm{mg} / \mathrm{L})}{\mathrm{Cl}}$ & $\underset{(\mathrm{mg} / \mathrm{L})}{\mathrm{Na}}$ & $\underset{(\mathrm{kg} / \mathrm{yr})}{\mathrm{Cl}}$ & $\underset{(\mathrm{kg} / \mathrm{yr})}{\mathrm{Na}}$ & $\begin{array}{c}\mathrm{CI} \\
\left(\mathrm{kg} / \mathrm{yr} / \mathrm{mi}^{2}\right)\end{array}$ & $\begin{array}{c}\mathrm{Na} \\
\left(\mathrm{kg} / \mathrm{yr} / \mathrm{mi}^{2}\right)\end{array}$ \\
\hline 24 & 01115190 & Dolly Cole Brook & 33 & 20 & 180,000 & 110,000 & 36,000 & 22,000 \\
\hline 28 & 01115265 & Barden Reservoir (Hemlock Brook) & 25 & 15 & 280,000 & 170,000 & 32,000 & 19,000 \\
\hline 3 & 01115280 & Cork Brook & 39 & 23 & 75,000 & 44,000 & 42,000 & 24,000 \\
\hline 5 & 01115184 & Spruce Brook & 24 & 14 & 36,000 & 21,000 & 29,000 & 17,000 \\
\hline 6 & 01115183 & Quonapaug Brook & 45 & 27 & 110,000 & 64,000 & 55,000 & 33,000 \\
\hline 7 & 01115297 & Wilbur Hollow Brook & 11 & 7.3 & 58,000 & 37,000 & 14,000 & 8,600 \\
\hline 19 & 01115170 & $\begin{array}{l}\text { Moswansicut Reservoir (Moswansicut Stream } \\
\text { North, Moswansicut Pond) }\end{array}$ & 53 & 31 & 160,000 & 94,000 & 49,000 & 29,000 \\
\hline \multicolumn{9}{|c|}{ Regulating Reservoir subbasin } \\
\hline 14 & 01115110 & Huntinghouse Brook & 13 & 8.0 & 91,000 & 54,000 & 15,000 & 8,700 \\
\hline 15 & 01115114 & Rush Brook & 41 & 25 & 220,000 & 130,000 & 47,000 & 28,000 \\
\hline 16 & 01115098 & Peeptoad Brook (Harrisdale Brook) & 49 & 28 & 300,000 & 170,000 & 60,000 & 34,000 \\
\hline 18 & 01115120 & $\begin{array}{l}\text { Unnamed tributary to Regulating Reservoir } \\
\text { (unnamed brook A) }\end{array}$ & 54 & 31 & 17,000 & 9,800 & 62,000 & 35,000 \\
\hline \multicolumn{9}{|c|}{ Scituate Reservoir drainage area } \\
\hline
\end{tabular}




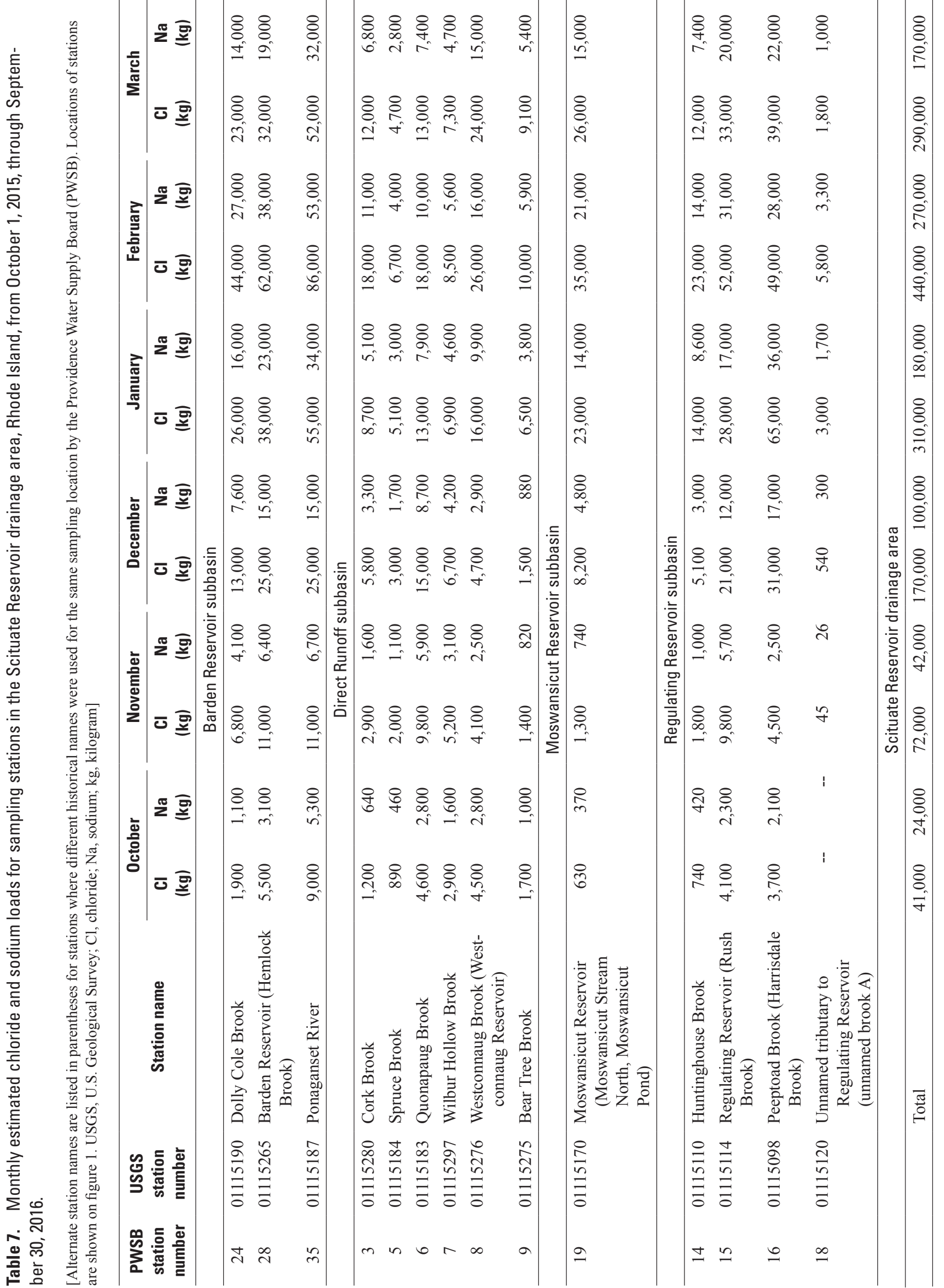




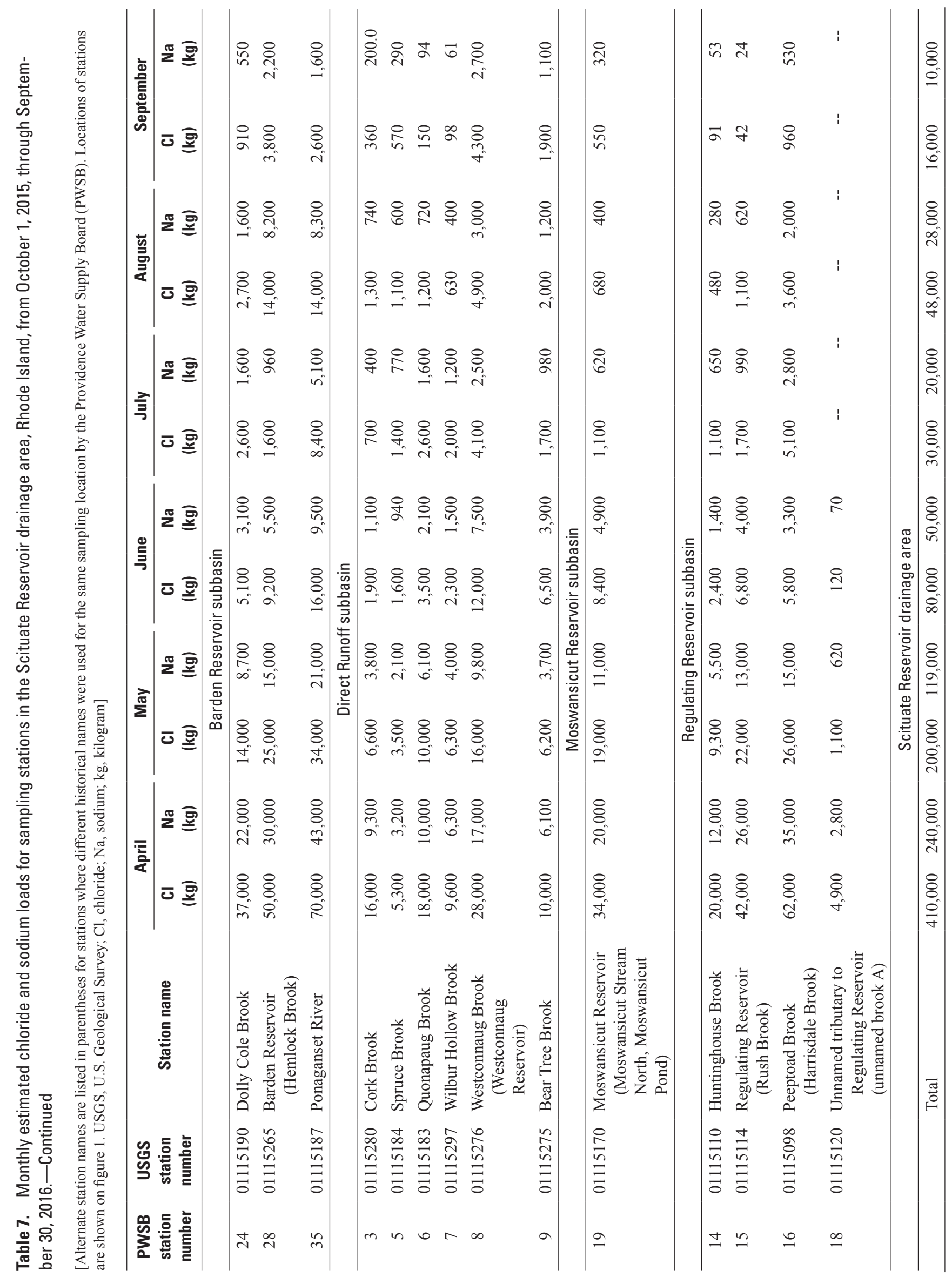




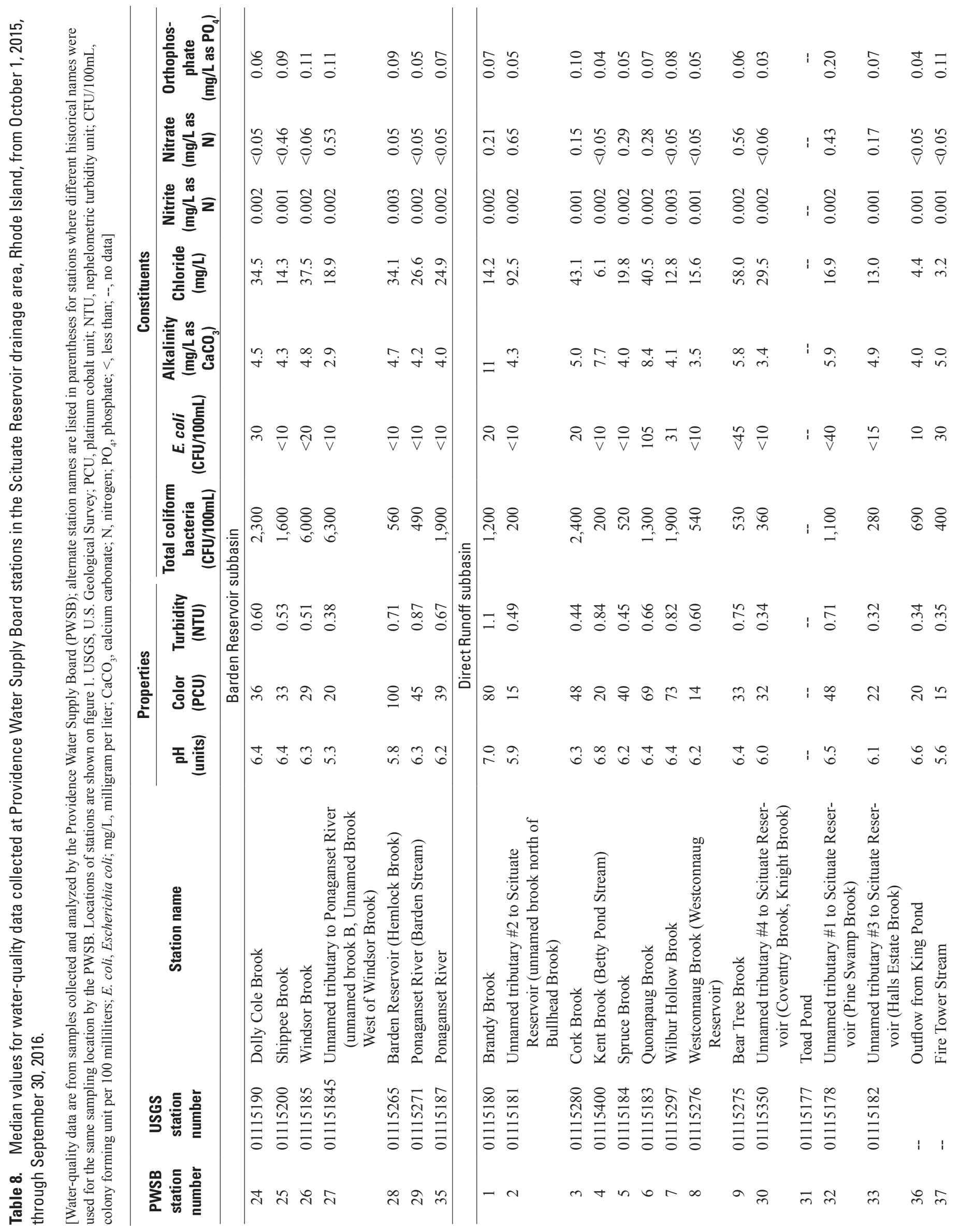




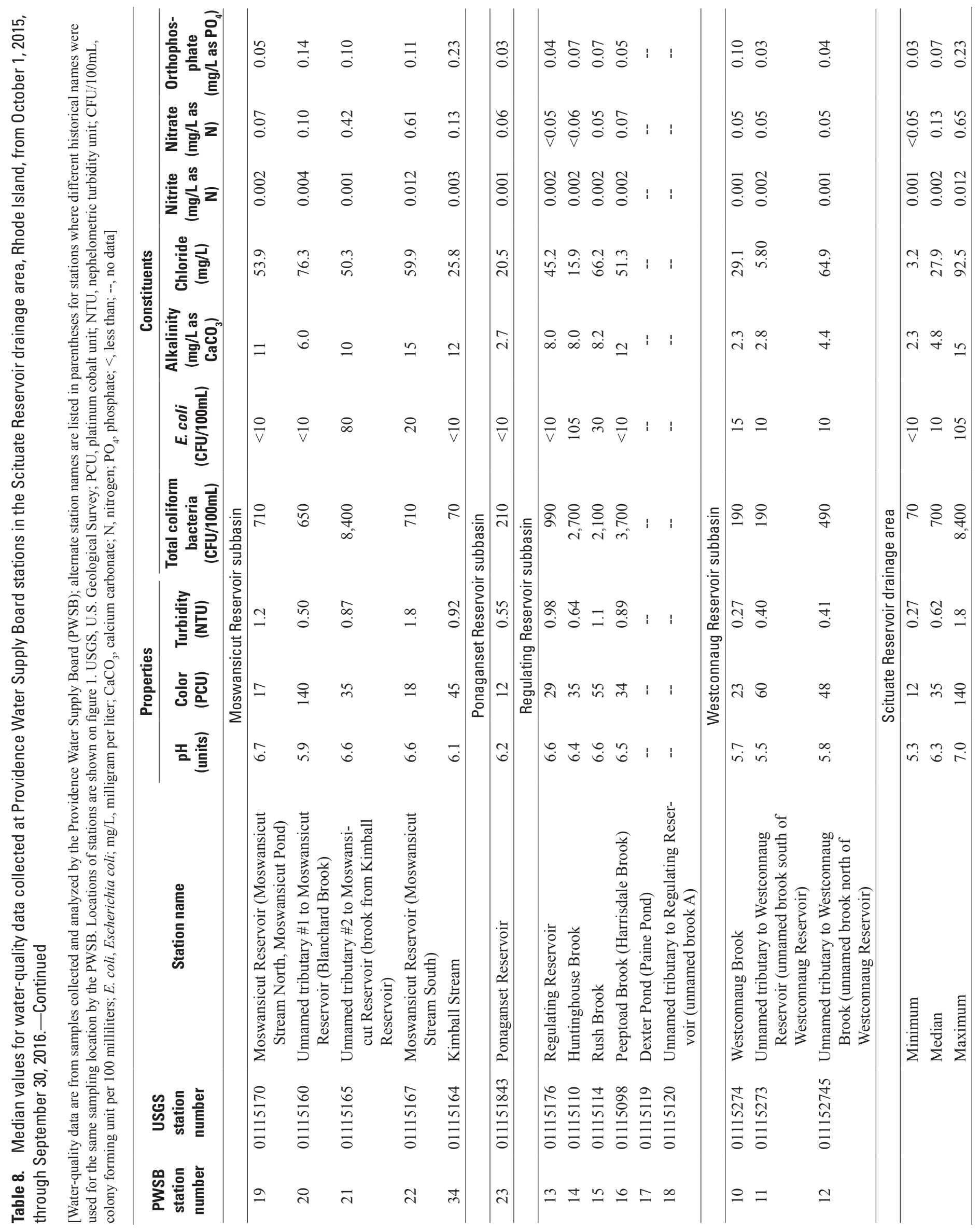




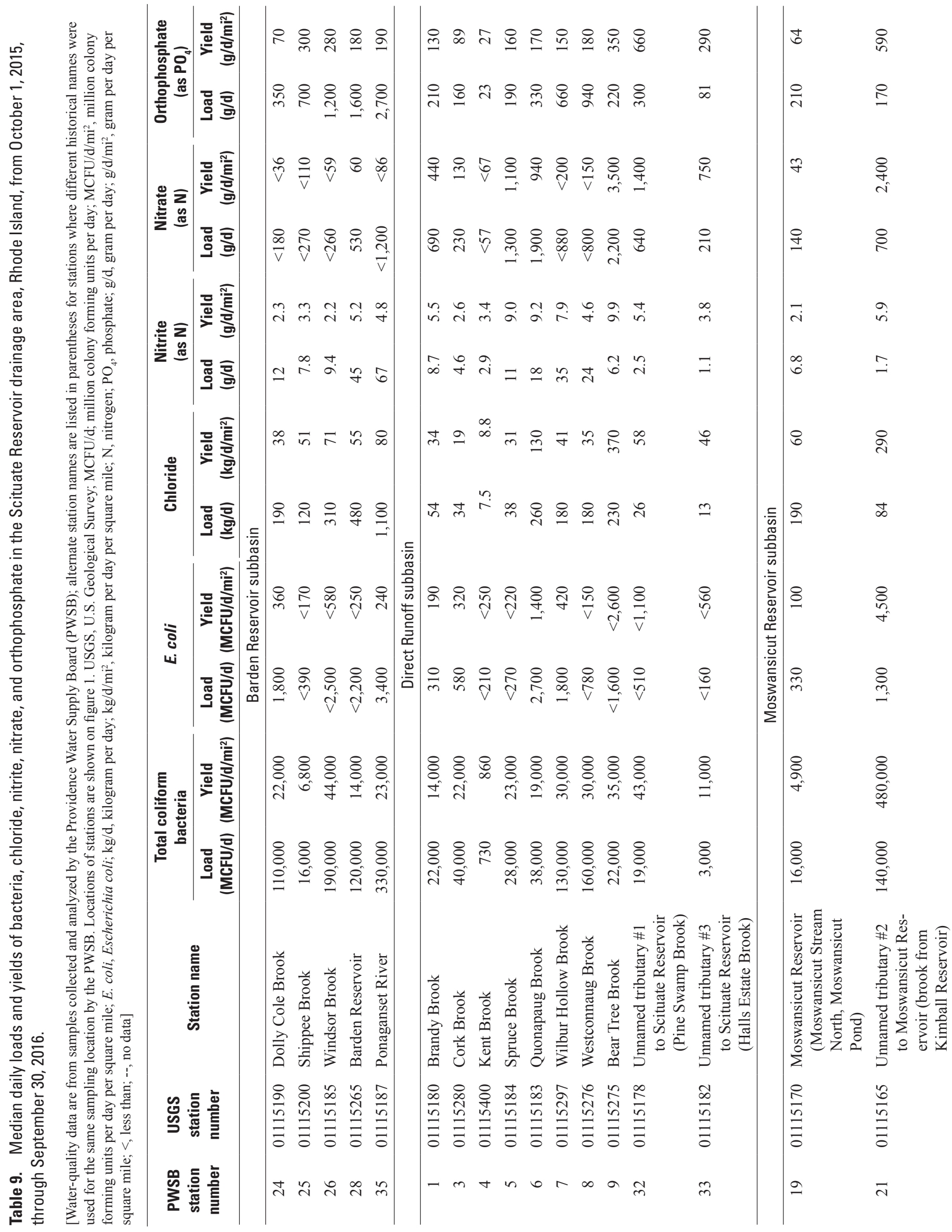




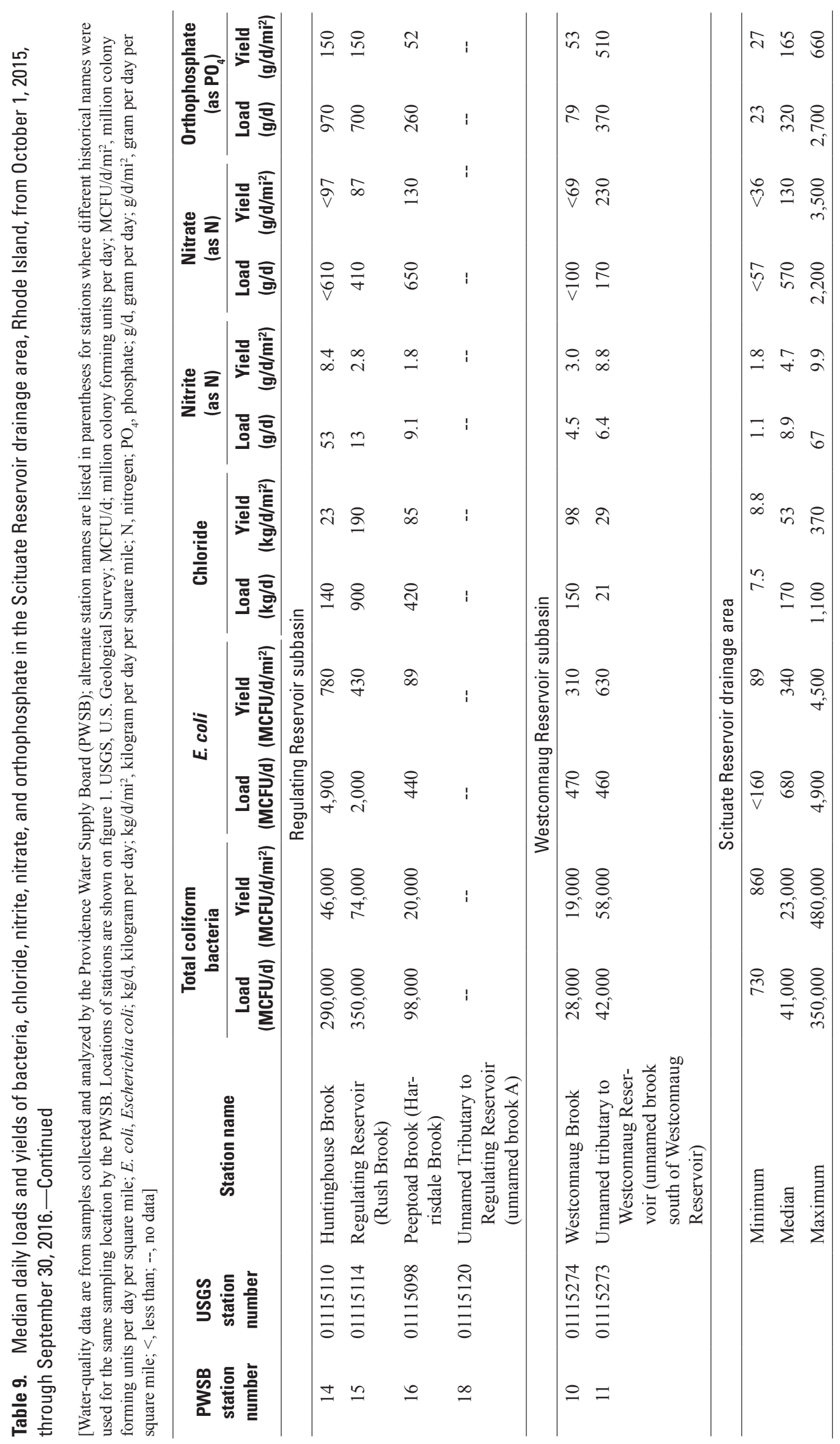




\section{References Cited}

Breault, R.F., 2010, Streamflow, water quality, and constituent loads and yields, Scituate Reservoir drainage area, Rhode Island, water year 2002: U.S. Geological Survey OpenFile Report 2009-1041, 25 p. [Also available at https://pubs.er.usgs.gov/publication/ofr20091041.]

Breault, R.F., and Campbell, J.P., 2010a, Streamflow, water quality, and constituent loads and yields, Scituate Reservoir drainage area, Rhode Island, water year 2003: U.S. Geological Survey Open-File Report 2010-1043, 24 p. [Also available at https://pubs.er.usgs.gov/publication/ofr20101043.]

Breault, R.F., and Campbell, J.P., 2010b, Streamflow, water quality, and constituent loads and yields, Scituate Reservoir drainage area, Rhode Island, water year 2004: U.S. Geological Survey Open-File Report 2010-1044, 24 p. [Also available at https://pubs.er.usgs.gov/publication/ofr20101044.]

Breault, R.F., and Campbell, J.P., 2010c, Streamflow, water quality, and constituent loads and yields, Scituate Reservoir drainage area, Rhode Island, water year 2005: U.S. Geological Survey Open-File Report 2010-1045, 24 p. [Also available at https://pubs.er.usgs.gov/publication/ofr20101045.]

Breault, R.F., and Campbell, J.P., 2010d, Streamflow, water quality, and constituent loads and yields, Scituate Reservoir drainage area, Rhode Island, water year 2006: U.S. Geological Survey Open-File Report 2010-1046, 25 p. [Also available at https://pubs.er.usgs.gov/publication/ofr20101046.]

Breault, R.F., and Smith, K.P., 2010, Streamflow, water quality, and constituent loads and yields, Scituate Reservoir drainage area, Rhode Island, water year 2009: U.S. Geological Survey Open-File Report 2010-1275, 24 p. [Also available at https://pubs.er.usgs.gov/publication/ofr20101275.]

Breault, R.F., Sorenson, J.R., and Weiskel, P.K., 2002, Streamflow, water quality, and contaminant loads in the lower Charles River watershed, Massachusetts, 1999-2000: U.S. Geological Survey Water-Resources Investigations Report 2002-4137, 131 p. [Also available at https://pubs.er.usgs.gov/publication/wri024137.]

Breault, R.F., Waldron, M.C., Barlow, L.K., and Dickerman, D.C., 2000, Water-quality conditions in relation to drainage basin characteristics in the Scituate Reservoir basin, Rhode Island, 1982-95: U.S. Geological Survey Water-Resources Investigations Report 2000-4086, 46 p. [Also available at https://pubs.er.usgs.gov/publication/wri004086.]

Eaton, A.D., Braun-Howland, Ellen, and Baxter, T.E., eds., 2017, Standard methods for the examination of water and wastewater ( $22 \mathrm{~d}$ ed.): Standard Methods website, variously paged, accessed October 4, 2017, at http://www.standardmethods.org/store/.
Hach Company, 2000, DR/2010 spectrophotometer procedures manual, rev. 2: Loveland, Colo., Hach Company, 657 p.

Helsel, D.R., and Hirsch, R.M., 2002, Statistical methods in water resources: U.S. Geological Survey Techniques of Water-Resources Investigations, book 4, chap. A3, 522 p. [Also available at https://pubs.usgs.gov/twri/twri4a3/.]

Hirsch, R.M., 1982, A comparison of four streamflow record extension techniques: Water Resources Research, v. 18, no. 4, p. 1081-1088. [Also available at https://doi.org/10.1029/WR018i004p01081.]

Hirsch, R.M., and Gilroy, E.J., 1984, Methods of fitting a straight line to data-Examples in water resources: Water Resources Bulletin, v. 20, no. 5, p. 705-711. [Also available at https://doi.org/10.1111/j.1752-1688.1984.tb04753.x.]

Nimiroski, M.T., DeSimone, L.A., and Waldron, M.C., 2008, Water-quality conditions and constituent loads, 1996-2002, and water-quality trends, 1983-2002, in the Scituate Reservoir drainage area, Rhode Island: U.S. Geological Survey Scientific Investigations Report 2008-5060, 55 p. [Also available at https://pubs.er.usgs.gov/publication/ sir20085060.]

Nimiroski, M.T., and Waldron, M.C., 2002, Sources of sodium and chloride in the Scituate Reservoir drainage basin, Rhode Island: U.S. Geological Survey Water-Resources Investigations Report 2002-4149, 16 p. [Also available at https://pubs.er.usgs.gov/publication/wri024149.]

Providence Water Supply Board Water Quality Laboratory, 2012, Quality assurance program manual: Providence Water Supply Board, [variously paged].

Ries, K.G., III, and Friesz, P.J., 2000, Methods for estimating low-flow statistics for Massachusetts streams: U.S. Geological Survey Water-Resources Investigations Report 20004135, 81 p. [Also available at https://pubs.er.usgs.gov/ publication/wri004135.]

Smith, K.P., 2013, Streamflow, water quality, and constituent loads and yields, Scituate Reservoir drainage area, Rhode Island, water year 2011: U.S. Geological Survey OpenFile Report 2013-1127, 32 p. [Also available at https://pubs.er.usgs.gov/publication/ofr20131127.]

Smith, K.P., 2014, Streamflow, water quality, and constituent loads and yields, Scituate Reservoir drainage area, Rhode Island, water year 2012: U.S. Geological Survey Open-File Report 2013-1274, 30 p. [Also available at https://doi.org/10.3133/ofr20131274.]

Smith, K.P., 2015a, Streamflow, water quality, and constituent loads and yields, Scituate Reservoir drainage area, Rhode Island, water year 2013: U.S. Geological Survey Open-File Report 2015-1082, 31 p., accessed June 3, 2015, at https://doi.org/10.3133/ofr20151082. 
Smith, K.P., 2015b, Water-quality trends in the Scituate reservoir drainage area, Rhode Island, 1983-2012: U.S. Geological Survey Scientific Investigations Report 2015-5058, 57 p. [Also available at https://doi.org/10.3133/ sir20155058.]

Smith, K.P., 2016, Streamflow, water quality, and constituent loads and yields, Scituate Reservoir drainage area, Rhode Island, water year 2014: U.S. Geological Survey Open-File Report 2016-1051, 31 p. [Also available at https://doi.org/10.3133/ofr20161051.]

Smith, K.P., 2018a, Streamflow, water quality, and constituent loads and yields, Scituate Reservoir drainage area, Rhode Island, water year 2015: U.S. Geological Survey Open-File Report 2018-1065, 28 p. [Also available at https://doi.org/10.3133/ofr20181065.]

Smith, K.P., 2018b, Water quality data from the Providence Water Supply Board for tributary streams to the Scituate Reservoir, water year 2015: U.S. Geological Survey data release, https://doi.org/10.5066/F7FJ2FR5.

Smith, K.P., 2018c, Water quality data from the Providence Water Supply Board for tributary streams to the Scituate Reservoir, water year 2016: U.S. Geological Survey data release, https://doi.org/10.5066/F7Z60NC5.

Smith, K.P., and Breault, R.F., 2011, Streamflow, water quality, and constituent loads and yields, Scituate Reservoir drainage area, Rhode Island, water year 2010: U.S. Geological Survey Open-File Report 2011-1076, 26 p. [Also available at https://pubs.er.usgs.gov/publication/ofr20111076.]
Tasker, G.D., and Driver, N.E., 1988, Nationwide regression models for predicting urban runoff water quality at unmonitored sites: Water Resources Bulletin, v. 24, no. 5, p. 1091-1101. [Also available at https://doi.org/10.1111/j.1752-1688.1988.tb03026.x.]

U.S. Environmental Protection Agency, 1993, Method 353.2, revision 2.0-Determination of nitrate-nitrite nitrogen by automated colorimetry: U.S. Environmental Protection Agency, [variously paged], accessed June 10, 2016, at https:/www.epa.gov/sites/production/files/2015-08/ documents/method_353-2_1993.pdf.

U.S. Geological Survey, 2016, Water data for the nation: U.S. Geological Survey National Water Information System web interface, accessed October 9, 2016, at https://doi.org/10.5066/F7P55KJN.

Wagner, R.J., Boulger, R.W., Jr., Oblinger, C.J., and Smith, B.A., 2006, Guidelines and standard procedures for continuous water-quality monitors-Station operation, record computation, and data reporting: U.S. Geological Survey Techniques and Methods, book 1, chap. D3, 8 attachments, accessed April 10, 2006, at https://pubs.er.usgs.gov/ publication/tm1D3. 


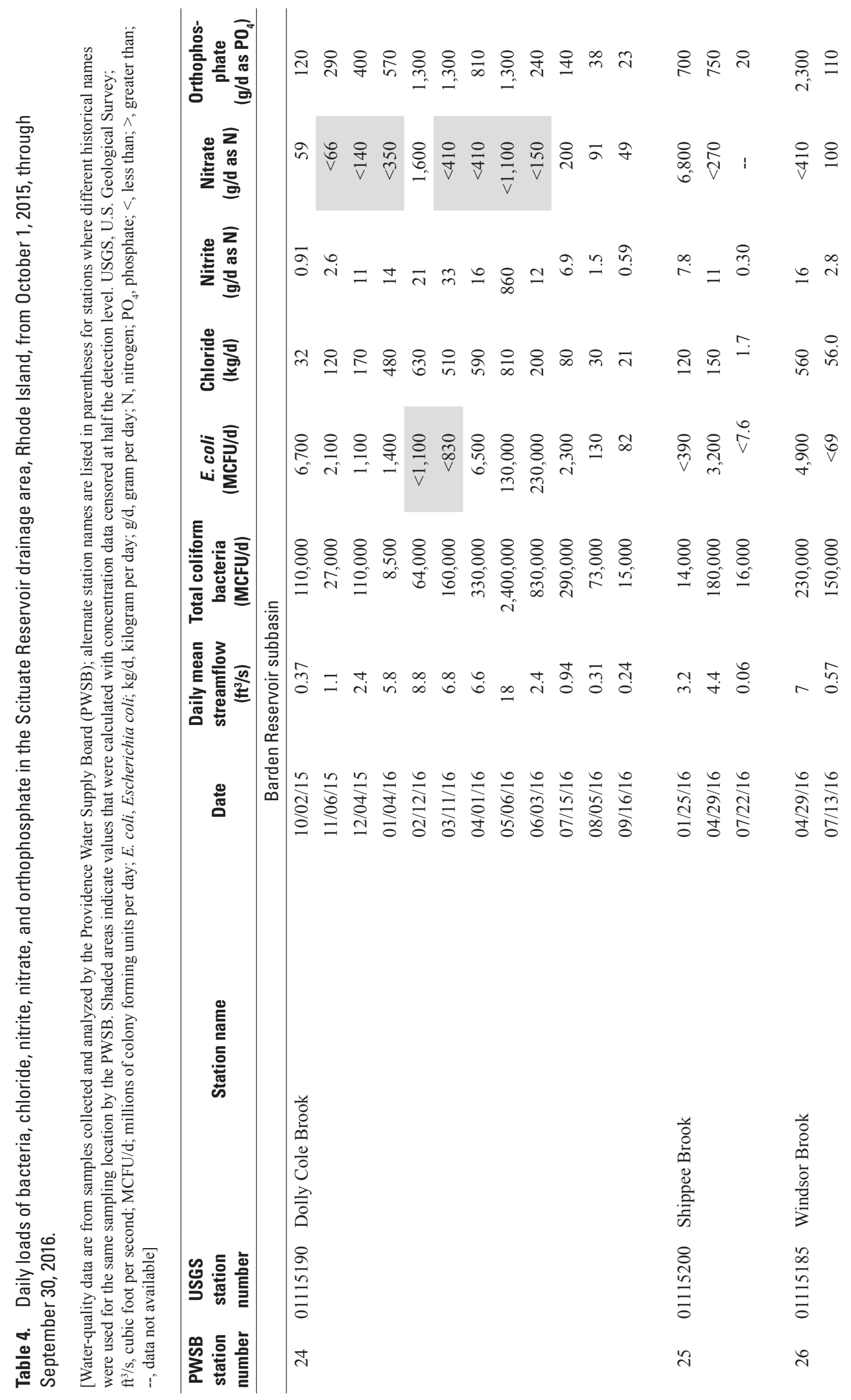




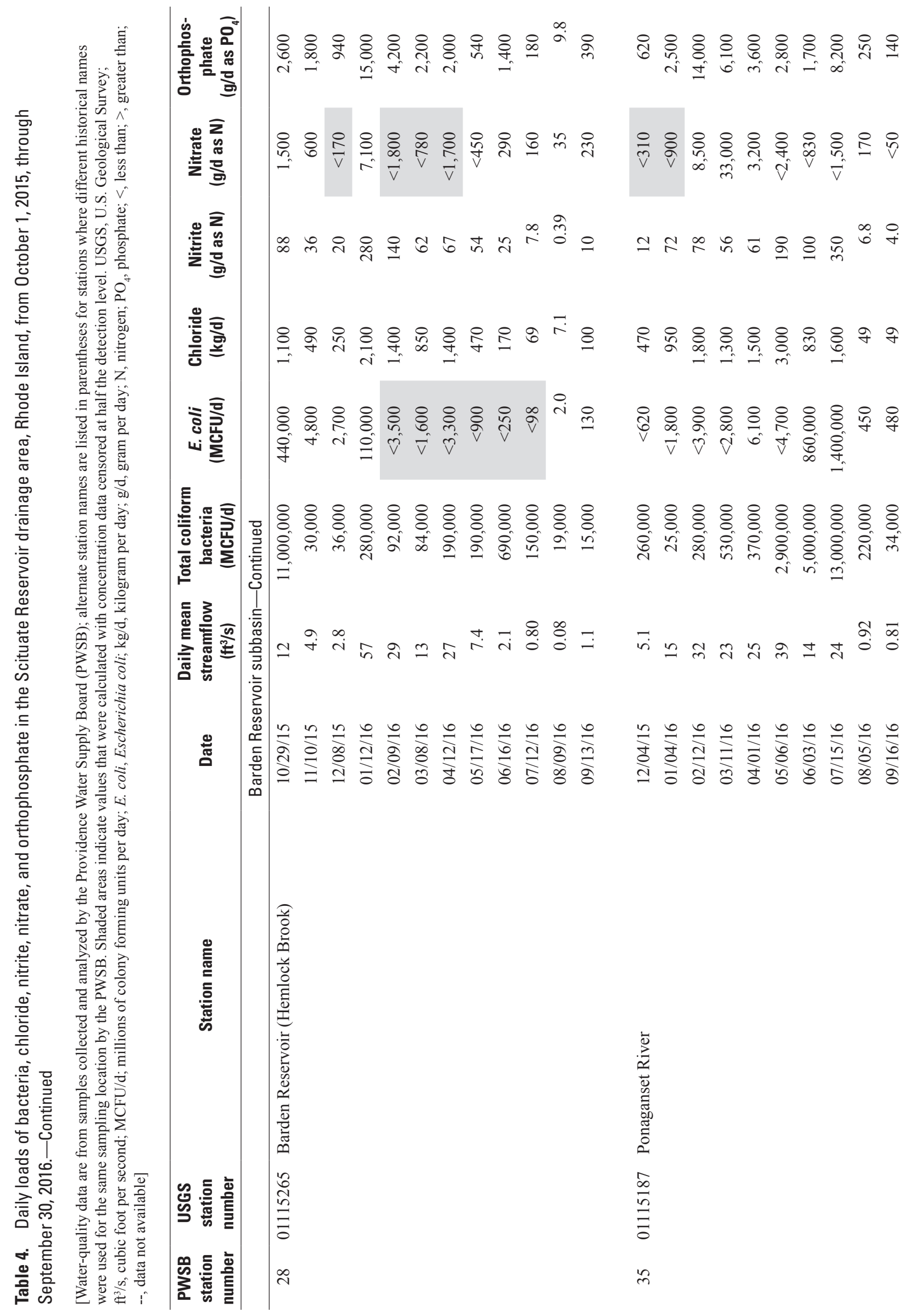




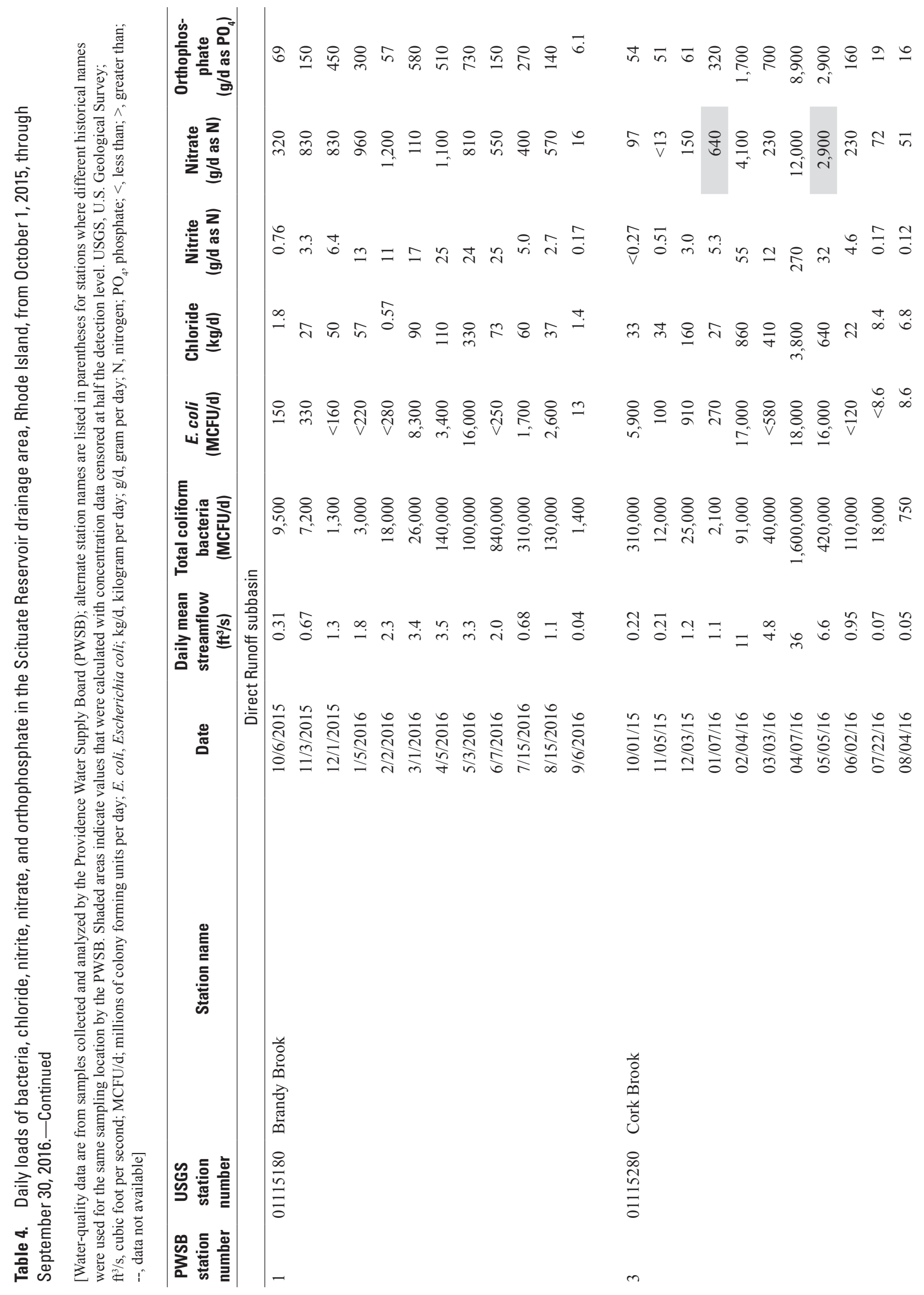




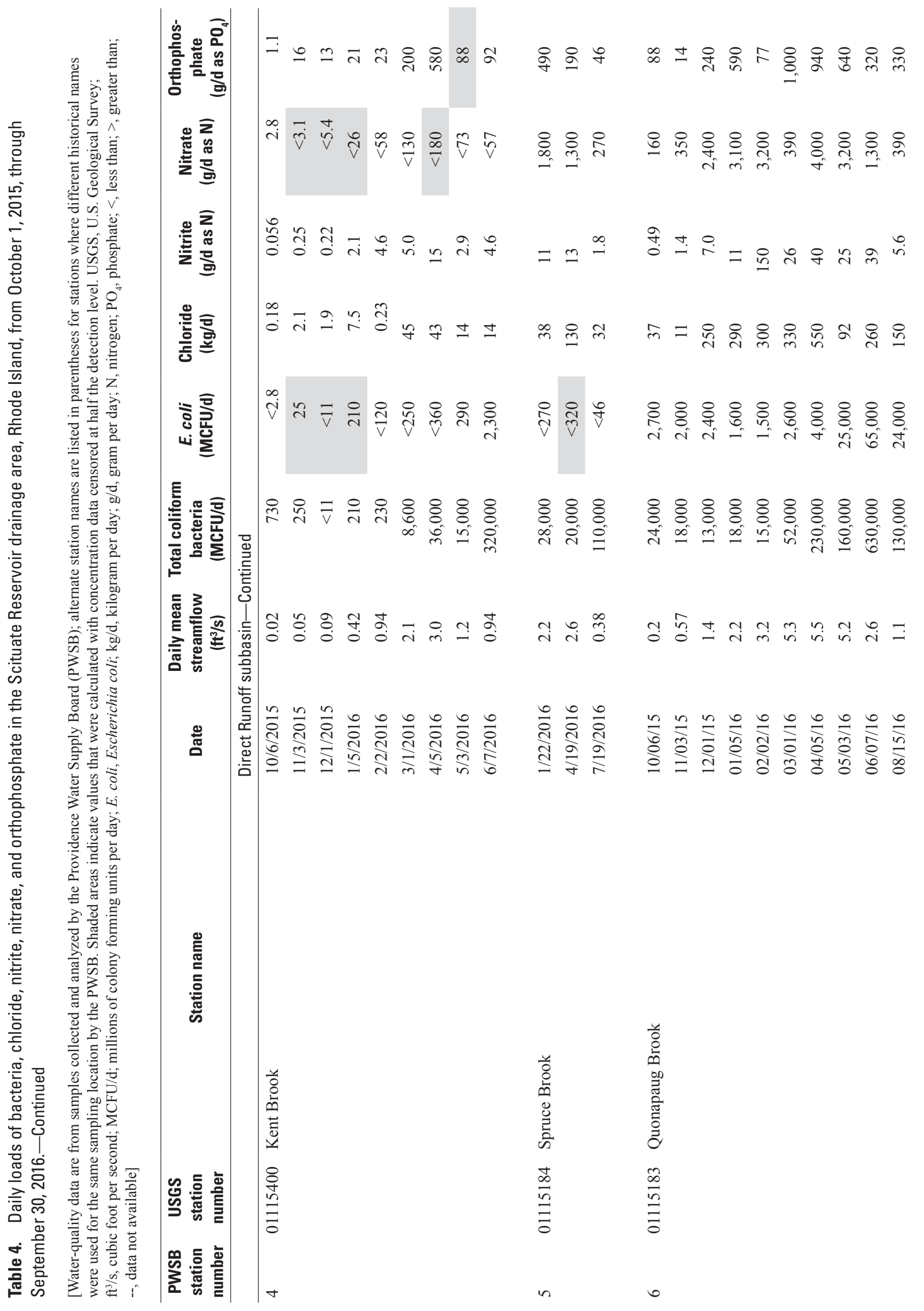




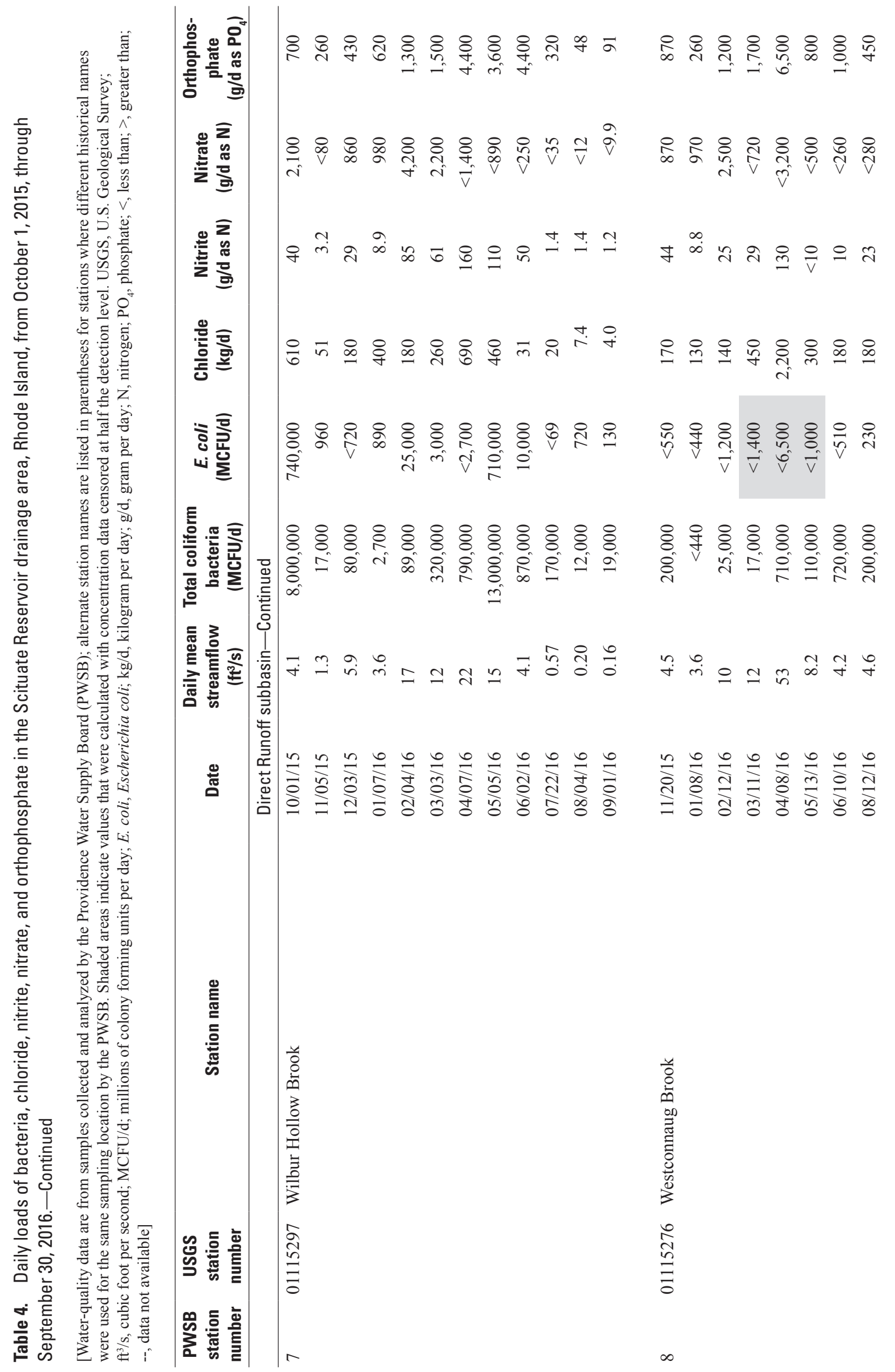




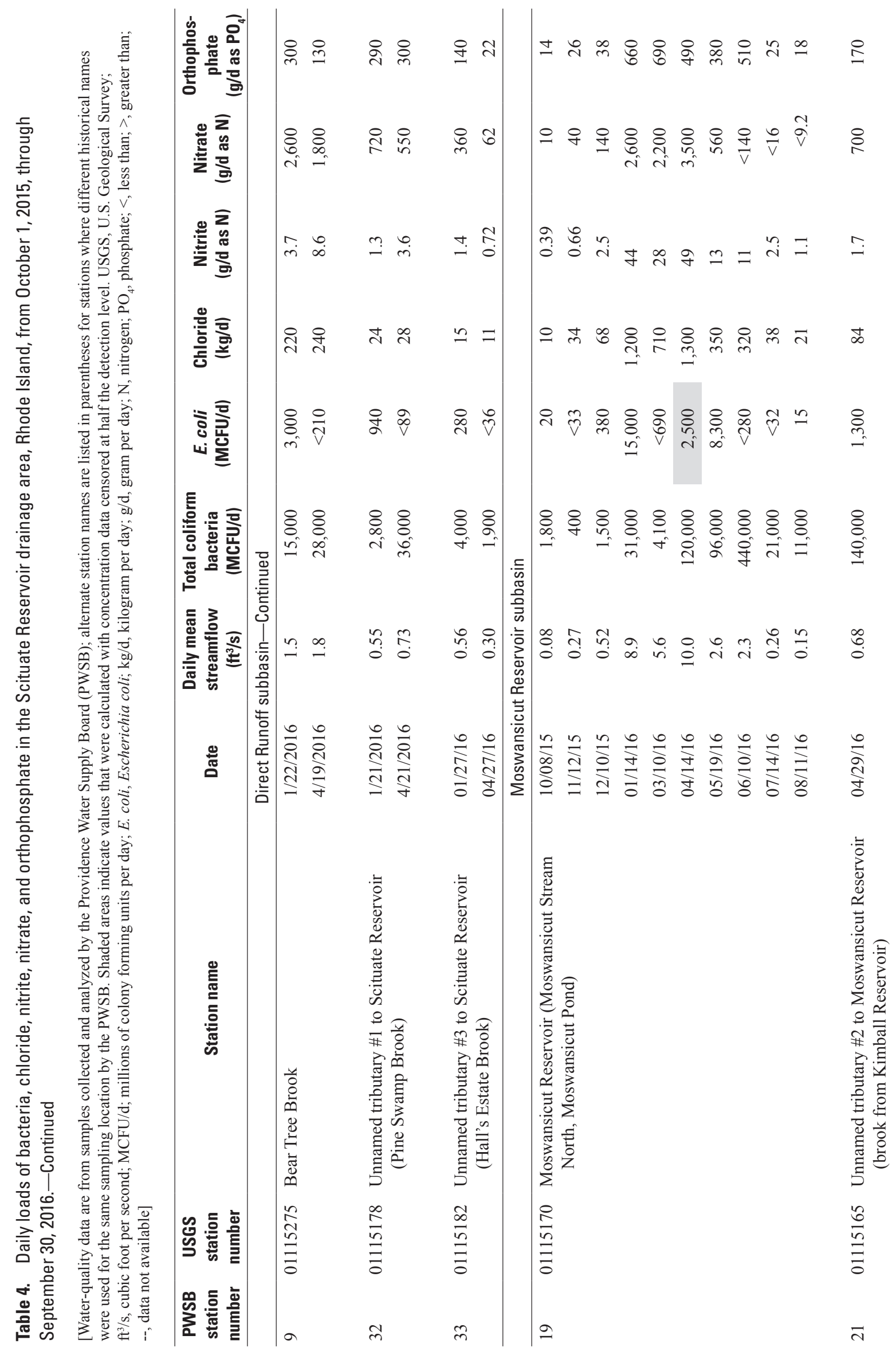




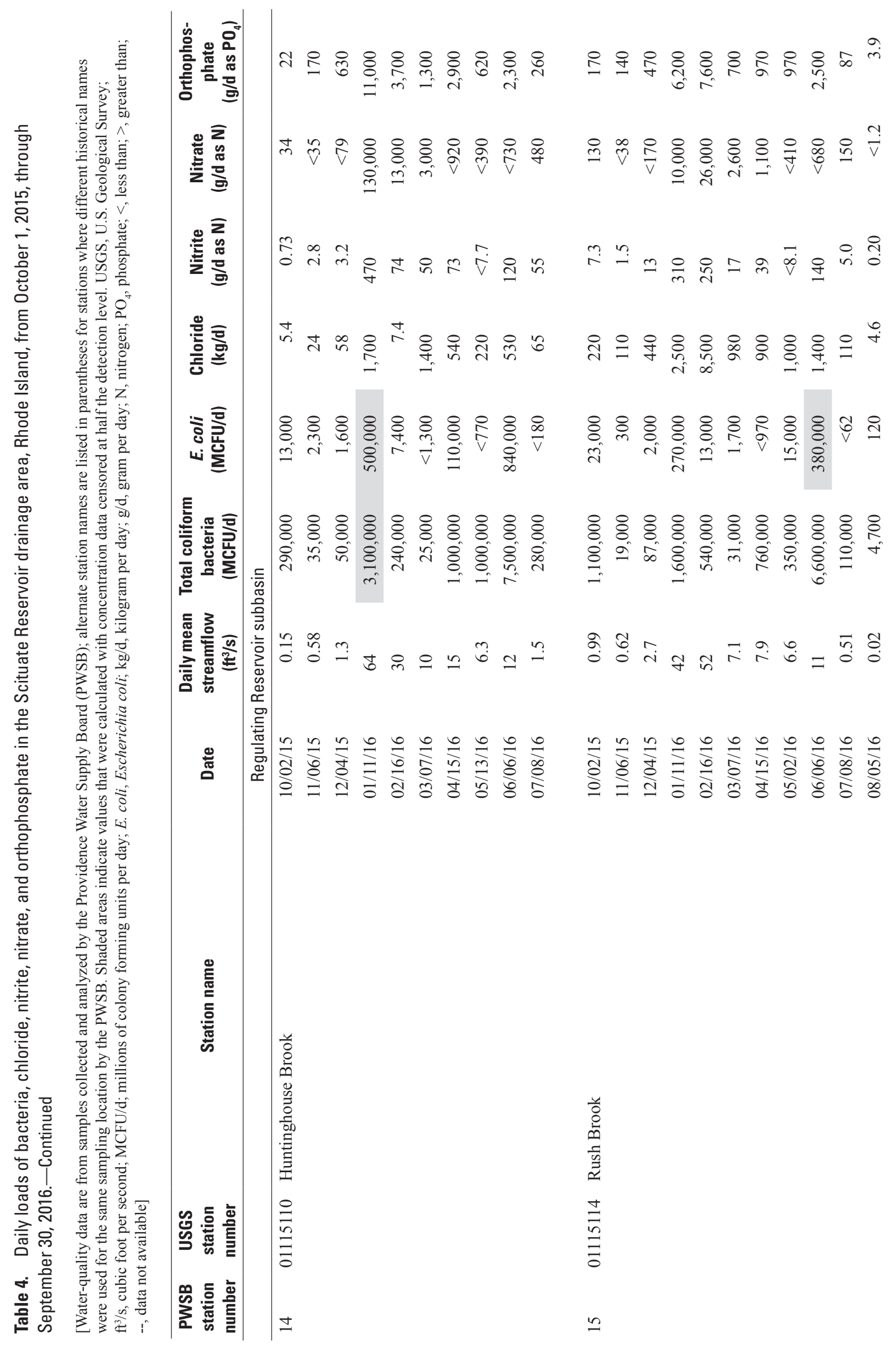




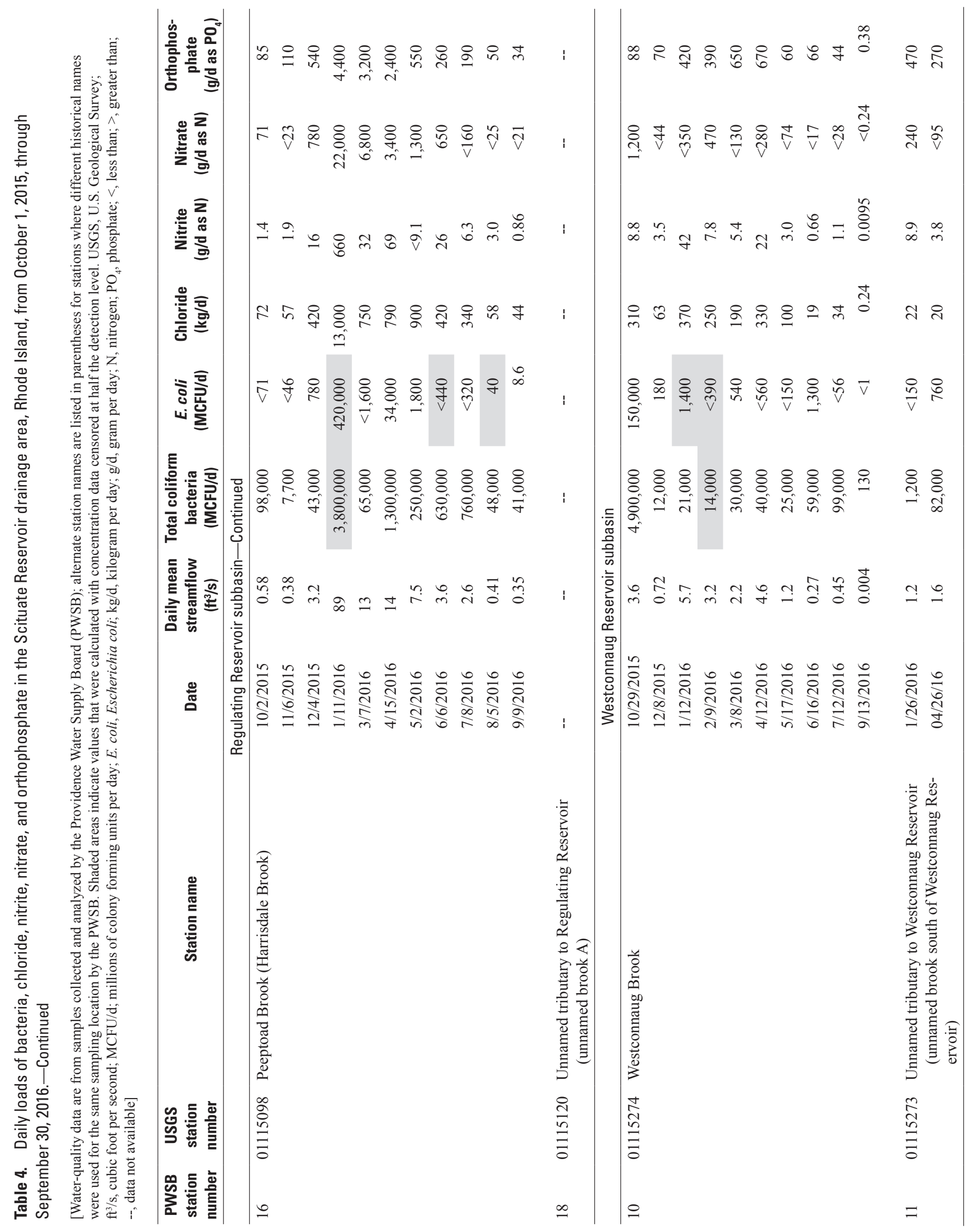


For more information about this report, contact: Director, New England Water Science Center U.S. Geological Survey

10 Bearfoot Road

Northborough, MA 01532

dc_nweng@usgs.gov

or visit our website at

https://newengland.water.usgs.gov

Publishing support provided by the Pembroke Publishing Service Center 
